Ankara Üniversitesi Türk Inkılâp Tarihi Ensitüsü Atatürk Yolu Dergisi S 24, Kasim 1999-2003 s. 527-56I

\title{
Fransız Arşiv Belgelerinin Işığında Chester Demiryolu Projesi
}

\author{
Doç. Dr. Bige Sükan Yavuz*
}

\section{ÖZET}

XIX. yüzyılda gelişen küresel rekabetin patlamaya dönüşmesi sonrasında çözümleri diplomatik müzakerelere bırakılan sorunlar, içinden çıkılması oldukça zor olan uzun tartışmaları davet etmiştir.

Nitekim, I. Dünya Savaşı'ntn bitmesini takiben oluşturulan diplomasi platformlarından biri de, ülke ve ulusumuzun geleceği ile doğrudan ilgisi olan sorunlarm tartışıldığı Lozan Konferansi'dır.

Burada, şimdiye kadar yapılmıs olan araştırmalara Fransız belgeleriyle katkıda bulunmaya çalışacağımız Chester Projesi, gerek içeriği gerekse projelendirildiği bölgenin uluslararası rekabetin tam kesişme noktasında bulunması nedeniyle, denilebilir ki, devletlerarası gizli çekişmelerin odağını oluşturmuştur. Başlangıcı 1908'lere giden, ancak Meclis-i Mebusan'da sonuçlanamayan Chester Demiryolu Projesi, 1922 yılında bu kez Ankara'nın gündemine oturmuştur. Proje görüntüsü itibari ile ulaşım ve kalkınma sorunlarının çözümü gibi insani amaçlara yönelik, masum bir izlenim vermektedir. Ancak, projenin işgal ettiği bölgenin hem siyasi hem de kaynak zenginliği açısından İngiltere ve Fransa gibi ülkelerin çok önceden dış politikalarının ilgi odă̆ı olduğu hatırlanırsa, bu iki ülkenin böylesi bir proje müzakerelerini başlatmış bulunan Türk-Amerikan bloğunun karşısına dikilmekte duraksama göstermeyecekleri açıktı ve nitekim de öyle olmuştur.

Chester Demiryolu Projesi, kısa zamanda, uzun vade hedefinin bölgenin sahip olduğu petrol kaynaklarının kontrol altına alınması olduğunun anlaşılması üzerine özelikle Fransa, Amerika ve Türkiye arasında son derece ince hesaplara dayalı gizli diplomasiyi davet etmiştir.

Yaptı̆̆ımız bu derinlemesine araştırmada, bir yandan bugün de bölgede devam eden uluslararası rekabetin Lozan görüsmelerinde ortaya çıkan ilk diplomatik boyutunu diğer yandan Chester Projesi ile ilgili tartışmaları Fransız belgelerinin ışı̆̆ında aydınlatmaya çalıştık.

\footnotetext{
* Ankara Üniversitesi Türk İnkılap Tarihi Enstitüsü Öğretim Üyesi.
} 


\begin{abstract}
Global competition which developed in the $19^{\text {th }}$ century, eventually transformed into an outburst leaving behind problematic diplomatic negotiations, inviting long lasting quarrels often too difficult to overcome.

Such was the Lausanne Conference, following the conclusion of the First World War, where the problems were directly related to the future of Turkish state and nation.

In this conference, the Chester Project to which this study aims to clarify further than the existing researches have, constituted the very focus of clandestine international competition because of its content or its existence at the overlapping points.
\end{abstract}

The Chester Project, the outset of which extended back to 1908 but could not be concluded in the Ottoman Parliament (Meclis-i Mebusan), came into the agenda of the Ankara government in 1922. The Project displayed the innocent image of being designed for solving the transportation problem. However when it is remembered that countries such as England and France strived to restrict the Project to their prosperous and fertile zones of interest for their resistance to the formation of Turco-American Block, is easily understood.

Nevertheless it was soon realized that the long-term objective of the Chester Railway Project was to seize petroleum resources of the region. Therefore, the Project led to a secret diplomacy over calculating plans between the US, Turkey and France in particular.

This extensive research, in the light of the French Archive Documents, intends to illuminate the first diplomatic aspect of the international competition emerged in Lausanne meetings as well as the contentions related to the Chester Project.

Doğu Sorunu adı altında Osmanlı İmparatorluğu'nu parçalamayı ve paylaşmayı düşleyen Batılı emperyalist devletlerin XIX. yüzyılda ve XX. yüzyıl başlarında izledikleri politikalar doğrultusunda gerçekleştirdikleri sermaye yatırımları, şimdiye kadar yerli ve yabancı çeşitli araştırmalara konu olmuştur. Osmanlı İmparatorluğu'nun stratejik ve jeopolitik konumunun yanı sıra sahip olduğu toprakaltı ve topraküstü zenginlikler, Birinci Dünya Savaşı öncesi uluslararası rekabeti beraberinde getirirken, bu durum savaş sonrası da devam etmiştir. Osmanlı İmparatorluğu'nda Birinci Dünya Savaşı öncesi en fazla yabancı sermaye yatırımının gerçekleştiği sektör olan demiryolları ise, sağladığı avantajlar (özellikle maden ve petrol yataklarının işletilmesi) açısından savaş sonrası yine Batılı devletlerin ilgi odağı olmuştur.

XIX. yüzyılın ikinci yarısından itibaren Osmanlı İmparatorluğu'nda demiryolları sektörüne yatırım yapan ülkeler İngiltere, Fransa ve Almanya 
iken, XX. yüzyılın başlarında hızlı bir emperyalizm sürecine giren ABD de bu alana el atıyordu. İşte başlangıcı 1908'li yıllara kadar giden, ancak Meclis-i Mebusan'da sonuçlanamayan, daha sonra 1922'lerde tekrar canlanan ve bu kez Ankara'nın gündemine giren bir Amerikan girişimi olan Chester Demiryolu Projesi, özellikle zengin petrol bölgesi Musul'un Amerikan sermayesinin denetimine geçmesi tehlikesi nedeniyle projenin başlarından itibaren bu yörede çıkarları olan devletleri rahatsız etmiştir. Araştırmamızın amacı, Chester imtiyazı hakkında şimdiye kadar gerek ABD'de gerekse ülkemizde yapılmış bilimsel çalışmalara, bu projeden rahatsızlık duyan devletlerden biri olan Fransa'ya ait bazı arşiv belgeleriyle katkıda bulunmaktır.

\section{Birinci Dünya Savaşı Öncesi Chester Projesi}

Demiryolu sektörü, İngiltere ve Fransa'ya göre kapitalist gelişmesini daha geç tamamlayan Almanya gibi ABD'nin de ilgisini çeken bir alandı. Şöyle ki, Akdeniz'i Basra Körfezi’ne bağlama sevdası çerçevesinde 1856 yılında İzmir-Aydın demiryolu imtiyazını elde eden İngiltere'nin ve de 1890'l y yllardan itibaren İzmir-Kasaba demiryolunu kontrol etmeye başlayan Fransa'nın yanı sıra İngiltere'nin sömürge yollarına sekte vurmak isteyen Almanya, 1888'den sonra Berlin-Bağdat demiryolu projesiyle bu emperyalist yarışa katılmıştı ${ }^{1}$. XIX. yüzyılın sonu ve XX. yüzyıl başlarında hızlı bir emperyalist çaba içine giren, bu arada Osmanlı İmparatorluğu'na da el atan, ancak Orta Doğu petrollerine yönelik arzuları İngiliz ve Alman çıkarlarıyla çakışan ABD ise, 1908'li yıllardan itibaren demiryolu ulaşım projeleriyle ilgilenmeye başlamıştı. 1908'de bir Amerikan demiryolu yapım ortaklığının temsilcisi olan Dr. Glaskow'un başvurusu üzerine, Osmanlı Hükümeti tarafından 99 yıllığına demiryolu hattının çevresindeki $40 \mathrm{~km}$.lik alan içindeki petrol dahil tüm maden yataklarının demiryollarının işletme imtiyazıyla birlikte yapımcı demiryolu şirketine bırakılması kararlaştırılmış, ancak ön anlaşma Osmanlı Meclis-i Mebusan'ında görüşülürken daha uygun koşullar önerisiyle başka istekliler de ortaya çıkmıştı. İşte Dr. Glaskow'un dışındaki altı istekliden birisi de Amiral Colby M. Chester idi ve 1870'li yıllardan sonraki Ermeni olayları sırasında zarar gören Amerikan mallarıyla ilgili bir tazminat almak için 1900 yılında İstanbul'a gelen Amerikan gemisinin kaptanıydı ${ }^{2}$. Nafia Vekâleti'ne başvuruda bulunan yedi projenin bir bölümünde Batı Anadolu ile Trakya'da bazı hatların yapımı önerilirken, "ittihat"ın sağlanması açısından Güney ve Doğu Anadolu'ya demiryolu ağının döşenmesini yeğleyen hükümet, bu yöreye ilişkin ilk değerlendirmeyi bir İngiliz-Amerikan firmasının kazanmış olmasına karşın projeyi daha

\footnotetext{
'Edward Mead Earle, Bağdat Demiryolu Savaşı, çev. Kasım Yargıcı, İstanbul, Milliyet Yayınları, 1972, s. 40-42,189; Vedat Eldem, Osmanlı Imparatorluğu'nun İktisadi Şartları Hakkında Bir Tetkik, Ankara, TTK, 1994, s. 97.

${ }^{2}$ Yahya Sezai Tezel, "Birinci Büyük Millet Meclisi Anti-Emperyalist miydi? Chester Ayrıcalığı," AÜ Siyasal Bilgiler Fakültesi Dergisi, C. XXV, No. 4 (Aralık 1970), s.288-290.
} 
yararlı koşullarda yapmayı öneren Chester'e ilgi gösteriyordu ${ }^{3}$. Osmanlı yöneticileriyle pazarlık aşamasındayken bazı büyük Amerikan petrol kapitalistlerinin ve Amerikan Hükümeti'nin desteğini kazanan Chester, 1909 'da Nafia Vekâleti ile ön sözleşme imzaladı. Bu sözleşmeye göre, Sivas ile Van arasında Harput, Ergani, Diyarbakır, Siirt ve Bitlis'ten geçen geniş bir hat ile bunu bir yandan Musul, Kerkük ve Süleymaniye'ye diğer yandan Adana yöresindeki Yumurtalık ya da Süveydiye'de Akdeniz'e bağlayacak yan hatların ve Yumurtalık veya Süveydiye'de bir limanının yapımı öngörülüyordu. Ancak bu ön sözleşme onay için Sadaret Makamı'na sunulunca, burada imtiyaz isteklisinin yararına olan birtakım değişiklikler yapıldı. Daha sonra proje, 1911'de kesin onay için Meclis-i Mebusan'a gönderildi. Yapılan değişikliklerle bu aşamada Harput'tan başlayarak Van'a değil, Van Gölü kenarında bir iskeleye ulaşacak dar bir hattın yapımı öngörülüyordu. Ayrıca Akdeniz'de varılacak yer ve yapılacak liman Yumurtalık oluyordu. Bunun yanı sıra Osmanlı Hükümeti Harput'tan Yumurtalık'a inecek demiryolu için kilometre garantisi verecek, ayrıca, demiryolu hattının çevresindeki 40 kilometrelik alanda bilinen ya da sonradan bulunacak petrol dahil tüm maden yatakları imtiyaz sahibine bırakılacaktı. Projenin son durumuna göre yapımı öngörülen hatların uzunluğu $2.000 \mathrm{~km}$ kadardı. Bu arada 1909 yılında Amerika'da The Ottoman-American Development Company (OADC)'i kuran Chester, her ne kadar bir ön sözleşme imzalamayı başarmış olsa bile yine de projesini sonuçlandıramayacaktı ${ }^{4}$. Üstelik proje, beraberinde tepki ve tedirginlikleri de getirecekti; şöyle ki, Musul'un Amerikan sermayesinin denetimine geçmesi olasılığının yanı sıra projenin Bağdat Demiryolu Projesi'ni tehdit etmesi İngiliz ve Alman çevrelerinin karşı koymalarına neden olurken, Rusya da Sivas-Samsun hattının kendi imtiyaz alanı olduğunu savunarak karşı çıkacaktı. Bu rahatsızlıkların yanı sıra Osmanlı Hükümeti'nin kapitülasyonların kaldırılması konusunda Amerikan Hükümeti'ni ikna etme arzusu, imtiyaz sözleşmesinin Osmanlı Meclis-i Mebusan'ında görüşülmesini geciktiren nedenlerdendi. Ne var ki ancak 1911 Haziranı'nda Meclis-i Mebusan'a gönderilen proje, zaman sıkışıklığından ötürü incelenemeyeceği gerekçesiyle başka bir zamana ertelendi. Bu arada kendi içinde sorunlar ve kopmalar yaşayan şirket (OADC), 1911 Eylülü'nün sonunda Trablusgarp Savaşı'nı bahane ederek yatırdığı teminatı geri aldı.

\footnotetext{
${ }^{3}$ Selim İlkin, "1922-1923 Yılları Türkiye'sinde Bir Yabancı Sermaye Girişimi: Chester Demiryolu Projesi," Türkiye İs Bankası Uluslararası Atatürk Sempozyumu: Bildiriler ve Tartışmalar, Ankara, Türkiye İş̧ Bankası Kültür Yayınları, 1984, s. 741.

${ }^{4}$ Tezel, AÜ Siyasal Bilgiler Fakültesi Dergisi, C. XXV, No. 4 (Aralık 1970), s.291-292. Selim İlkin'in ve Bilmez Bülent Can'ın çalışmalarında, Chester'in hazırladığı ilk projede üç yan hattın öngörüldüğü, birinin Samsun üzerinden Karadeniz'e, diğerinin Halep üzerinden Akdeniz'e, üçüncüsünün ise Bitlis üzerinden Van'a gideceği belirtilmektedir. İlkin, Türkiye Iş Bankası Uluslararası Atatürk Sempozyumu: Bildiriler ve Tartışmalar, s.742; Bilmez Bülent Can, Demiryolundan Petrole Chester Projesi (1908-1923), İstanbul, Tarih Vakfi Yurt Yayınları, 2000, s.136.
} 
Ancak M. Chester, 1912-1913 yıllarında inatla projeyi sürdürmeye çalışt1, hatta İttihatçı liderlerden Cavit Bey'in şirketin projeyi yeniden gündeme getirmesini istediği yolundaki söylentilerden sonra ABD'nin en ünlü bankeri Morgan'ın temsilcisi İstanbul'a geldi; ancak bu girişimden olumlu sonuç alınamadığı gibi şirket de dağılmaktan kurtulamadı. Chester, daha sonra Ottoman-American Exploration Company adlı yeni bir şirket kurmasına ve eski projede bazı değişiklikler yaparak yeni bir öneri hazırlamasına karşın, Haziran 1913'de Mahmut Şevket Paşa suikastı sonrası yeni yöneticilerin projeye sıcak bakmamaları nedeniyle istediği sonuca ulaşamad ${ }^{5}$.

\section{Kurtuluş Savaşı Yıllarında Türk-Amerikan Ekonomik İlişkileri ve Chester Projesi'ni Canlandırma Çalışmaları}

Amiral Colby M. Chester, Birinci Dünya Savaşı'ndan sonra 1920 başlarında projeyi canlandırmak amacıyla ABD Dışişleri Bakanlığı'na başvurdu. Ancak ABD Dışişleri Bakanlığı'ndan gerekli ilgi görmeyen Chester, daha sonra ABD Deniz Kuvvetleri Bakanlığı nezdinde bazı girişimlerde bulunacak, hatta bazı Amerikan petrol şirketleriyle görüşmeler yapacaktı. Ne yazık ki, tüm bu çabaları hiçbir sonuç vermeyecekti ${ }^{6} .1921$ yılında da ABD Dışişleri Bakanlığı'ndan birkaç kez destek talebinde bulunan, ancak her başvurusunda Dışişleri'nin temkinli ve olumsuz tavrıyla karşılaşan Amiral Chester'i tüm bu olumsuzluklar davasından caydırmaya yetmeyecekti. 1922 Şubatı'nda ise, bir kez daha ABD Dışsişleri Bakanlığı'na başvuran Chester, burada yine beklediği ilgiyi görememesine karşın gerek Amerikan iş çevrelerinden kimseleri gerekse tanınmış bazı kişileri projesine katılmaları konusunda ikna etti. Sonuçta grubun güçlü bir organizasyon kurma çabaları sonuç verdi ve 1922 Martı'ında Delaware'de OttomanAmerican Development Company (OADC) kuruldu. Bu şirket, Birinci Dünya Savaşı öncesi Chester tarafından kurulan Ottoman-American Exploration Company'nin tüm mal varlığını devralarak bazı değişikliklerle yeniden kurulmuş haliydi; ancak Chester artık hisselerin çoğunluğuna sahip değildi. Bu arada yeni şirket, en önemli adamlarından biri olan Kanadalı Binbaşı Clayton-Kennedy'i Amiral Chester'in İstanbul'daki American Shipping Board'da temsilci olarak çalışan oğlu Arthur Chester ile birlikte Ankara Hükümeti nezdinde imtiyaz görüşmelerini başlatmak üzere bölgeye gönderme kararı almıştı. Şirket bölgede projeyi canlandırma girişimlerini bașlatmadan önce yine Amerikan Dışişleri Bakanlığı'na bașvurdu, ama her zamanki gibi, beklediği desteği bulamadı. Ancak, bu sıralarda, yani 1922 başlarında, Ankara'daki bazı gelişmeler, projenin geleceği açısından ümit veriyordu ${ }^{7}$.

${ }^{5}$ İlkin, Türkiye İ̧ Bankası Uluslararası Atatürk Sempozyumu: Bildiriler ve Tartışmalar, s.742-744.

${ }^{6}$ A.g.m., s.744.

${ }^{7}$ Can, s.222-225, 231-236. 
ABD'nin İstanbul'daki Ticaret Ataşesi Gillespie'nin, 1921 Aralığ 1922 Şubatı arasında Ankara'ya yaptığı ziyaret sırasında Ankara Hükümeti'nin Amerikan sermayesine bakış açısı hakkında edindiği izlenim son derece olumluydu. Gillespie'nin 40 madde halinde hazırladı $\breve{g}_{1}$ ve Ankara Hükümeti'ne sunduğu sorulardan elde ettiği sonuca göre, TBMM Hükümeti Amerikan sermayesini ve Amerikan şirketlerini ülkesinde görmek istiyordu. Gillespie'nin sorduğu sorular arasında Chester Projesi ile ilgili bir soru da bulunuyor ve hükümet buna verdiği yanıtta, her türlü imtiyaz anlaşması için somut öneriler beklediklerini, ayrıca Türk sermayesinin katılımı ve Türk kontrolünde olması koşuluyla tekellere karşı olmadıklarını bildiriyordu. Türk Hükümeti'ni $\mathrm{ABD}$ ile ekonomik ve ticari ilişkiler kurmaya iten nedenler ise oldukça ilginçti. Şöyle ki, Gillespie'nin de belirttiği gibi, Türklerin mali desteğe ihtiyaçları vardı; ancak, dış borç olanağının dışında ABD Hükümeti'nin Avrupalılardan farklı olarak Amerikan sermayesi adına Türkiye'nin iç işlerine karışmayacak olması Türkleri ABD'ye yaklaştıran temel nedenlerdendi. Bunun da ötesinde, Türkler ABD'ye ekonomik öncelik ve ayrıcalıklar sağlayarak, ileride toplanacak bir barıs konferansında Avrupalı güçlerin ülkelerinden ekonomik ve ticari haklar talep etmelerini engellemeyi amaçlıyorlardı. Dolayısıyla, gerek Chester Projesi'nin canlandırılmasına gerekse Amerikalıların Musul petrollerinin işletilmesine katılmasına sıcak bakıyorlardı ${ }^{8}$.

ABD'nin Türkiye'ye ve bölge petrollerine olan ilgisi Musul petrollerinde hak iddia eden İngilizler'in dikkatinden kaçmıyordu. İstanbul'daki İngiliz Yüksek Komiseri'ne göre, Kafkasya ve İran'ın yanı sıra Anadolu'nun Doğu illerinde bulunduğuna inandıkları petrol kaynaklarıyla yakından ilgilenen Amerikalılar, bu nedenle Türkiye ile yakın ilişki kurup buradaki etkinliklerini artırdılar'. Ancak, Amerikalıların bölgedeki faaliyetlerini yakından izleyen bir başka ülke daha vardı: Fransa. Daha başından beri kendi nüfuz alanlarına yönelik Chester demiryolu projesinden rahatsız olan Fransızlar ${ }^{10}$, Amerikalıların Yakın Doğu'daki ekonomik nüfuzlarını artırmak amacıyla 1922 başlarında gösterdikleri çabaları göz ardı etmiyorlardı. Fransız istihbarat raporlarına göre $\mathrm{ABD}$, Türkiye ile olan ekonomik ve ticari ilişkilerine büyük önem vermeye başlamıştı. Bunun göstergeleri ise; Amerikan sermayesinin Türkiye'deki yabancı şirketlere ortak olması, İstanbul'da pek çok Amerikan kuruluşunun oluşturulması, hatta bir Amerikan bankasının açılması, bazı Amerikalı sermayedarların Ankara Hükümeti nezdinde girişimler başlatarak önerilerde bulunması ve de NewYork Ticaret Odası'nın Amerikalı tüccarları Doğu ticaretinde etkin rol

${ }^{8}$ A.g.e., s. 215-216; Ilkin, Türkiye Işs Bankası Uluslararası Atatürk Sempozyumu: Bildiriler ve Tartışmalar, s. 745-746.

${ }^{9}$ A.g.e., s. 216.

${ }^{10} 29$ Temmuz 1911'de Fransiz Régie Générale des Chemins de Fer ile Türk Nafia Nezareti arasında Rumeli ve Anadolu'da demiryolu yapımı ile ilgili bir anlaşma imzalanmıştı. A.g.e., s. 147. 
oynamaya davet ederek onlan bu konuda cesaretlendirmesi idi. Dolayısıyla tüm bu gelişmeler, ABD'nin Yakın Doğu'da sanayi ve ticaret alanlarında Avrupalı güçlerle rekabet etme kararlılığını gösteriyordu ${ }^{11}$.

Amerikalıların Anadolu'daki faaliyetleriyle ilgili olarak özellikle 1922 Martı'nda aldıkları duyumlar da Fransızları oldukça rahatsız ediyordu. Şöyle ki, "Anadolu'da bazı demiryollarının yapım imtiyazını almak için Amerikalı sermayedarların Ankara Hükümeti ile başlattıkları görüşmelerin oldukça ileri bir aşamaya geldiği ve de Amerikalıların kilometre garantisinden vazgeçerek yalnızca demiryolu hattının iki yanında bulunan 25 'er kilometrelik alanda bulunacak madenlerin imtiyazını talep ettikleri, bunun yanı sıra İstanbul'da görev yapan Amerikan Ticaret Ataşesi Gillespie'nin Ankara'dan Amerikalı sermayedarlar için Sivas-Samsun, Sivas-Erzurum demiryolları ve Samsun, İnebolu limanları imtiyazını aldı̆̆ı" yönündeki istihbarat raporları Fransızları oldukça tedirgin ediyordu. Ayrıca, "New-York menşeli 'Cavendish et Fondation' şirketinin yanı sıra Kanada (gerçekte İngiliz) çıkarlarını temsilen Ankara'ya gelen Amerikalı MacDowel'ın, Bitlis-Diyarbakır-Urfa-Antep üzerinden Yumurtalık limanına uzanacak bir demiryolu yapımını önerdiği, bunun dışında Yumurtalık Limanı imtiyazını ve bu limandan Musul'a, Samsun'dan Sivas'a, Adana'dan Erzurum'a uzanacak demiryolu hatlarının imtiyazını talep ettiği, bunun karşılığında ise Ankara Hükümeti'ne 20 milyon liralık bir borç vermeyi üstlendiği" yolundaki duyumlar, özellikle Kilikya demiryollarındaki ve Mersin limanındaki Fransız çıkarlarını tehdit etmesi açısından son derece rahatsız ediciydi ${ }^{12}$. Şöyle ki Ankara Hükümeti, Mersin'de liman yapımı ve işletmesine talip olan Paris menşeli "Groenland" şirketinin önerilerini kabul etmişti. Fransız şirketinin temsilcisi, sadece Mersin Limanı'nı büyütmeye değil, aynı zamanda rıhtım ve diğer eklentileri (gümrük binaları, bir demiryolu istasyonu vb.) de yapmaya talip olmuş ve Nafia Vekâleti ile anlaşmaya varır varmaz, uzun çalışmalar sonucu hazırlanan sözleşmeyi şirketinin onayına sunmak üzere Fransa'ya hareket etmişti. Sözleşme Paris'teki şirket tarafından onaylandığı takdirde temsilci Ankara Hükümeti'nin talep ettiği teminatla Ankara'ya dönecek ve de 1 Mayıs 1922'den itibaren çalışmalara başlanacaktı. Liman, rıhtım vb. yapım çalışmaları en fazla dokuz senede tamamlanacak, imtiyaz süresi ise 75 yıl

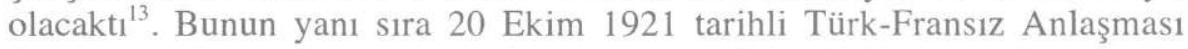
(Ankara Anlaşması)'nın 10. maddesine göre, TBMM Hükümeti, Pozantı ile Nusaybin arasındaki Bağdat demiryolu kesimine ilişkin imtiyaz hakkının ve Adana ilinde yapılmış bulunan kolların bu imtiyaz haklarına bağlı tüm hak,

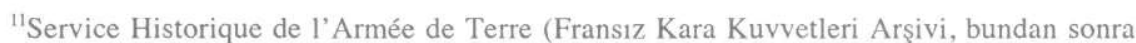
Château de Vincennes), 7 N 3257, D. 1, 25.2.1922 tarihli "Revue Commerciale d'Orient" kaynaklı, "Développement de l'influence économique de l'Amérique dans le Proche-Orient" başlıklı, 10.3.1922 tarihli Fransız istihbarat raporu, s. 29.

${ }^{12}$ Château de Vincennes, 7 N 3257, D. 1, "Les Américains en Anatolie" başlıklı, 10.3.1922 tarhli Fransız istihbarat raporu, s. 22.

${ }^{13}$ Château de Vincennes, 7 N 3257 , D. 1, 25 Mart 1922 tarihli "Information d'Orient" ve "Economiste d'Orient" kaynaklı, 31.3.1922 tarihli Fransız istihbarat raporu, s. 22.
} 
izin ve avantajlar ile birlikte Fransız Hükümeti'nin seçeceği bir Fransız grubuna devredilmesini kabul etmişti. Dolayısıyla Ankara Hükümeti, Bağdat demiryolunun Kilikya girişi ile Nusaybin arasındaki kısmının imtiyaz hakkını Fransızlara vermeyi kabul etmişti ${ }^{14}$.

Esasında Fransızlar bu endişelerinde çok da haksız değillerdi. Chester Grubu'nun Ankara Hükümeti nezdinde girişimlerini başlatmasından kısa bir süre önce Ankara Hükümeti yetkilileriyle görüșen Mac Dowell, İstanbul'daki Amerikan Yüksek Komiseri Bristol'e gönderdiği 8 Mart 1922 tarihli yazısında, Ankara Hükümeti'nin bu kez bir imtiyaz sözleşmesi yapmaya niyetli olduğunu bildiriyordu. Mac Dowell, Nafia Vekili Feyzi Bey'e başvurarak iki alternatif demiryolu güzergâhı önermişti: birisi İskenderun Körfezi'nde Ayas yakınlarında bir limandan başlayıp Maraş-Antep, Malatya, Ergani, Diyarbakır-Mardin, Van Gölü ve Musul bölgelerinden geçerek İran sınırına giden güzergâh, diğeri ise Samsun yakınlarında bir limandan başlayıp Amasya, Sivas, Harput, Ergani, Diyarbakır-Mardin, Van Gölü ve Musul üzerinden İran sınırına giden güzergâh. Mac Dowell'in Nafia Vekili'ne yaptığı öneriye göre, ayrıca, imtiyaz sahibi şirket kilometre garantisi istemeyeceği gibi Türklerin şirkete ortak olmasını ve Türk yasalarının geçerliğini kabul edecek, Hükümet ise demiryolu hattının iki yanındaki 20'şer kilometrelik alan içinde bulunan maden yataklarını ve hidroelektrik santrallerini işletme hakkını şirkete verecekti. Feyzi Bey'in bu öneriye verdiği cevap ise olumluydu; böyle bir imtiyaz anlaşmasına hazır olunduğu ve önerilen demiryolu güzergâhlarından ikincisinin uygun görüldüğg̈ vurgulanıyordu. Sonuçta, Ankara Hükümeti'nin Chester'in Birinci Dünya Savaşı öncesi elde etmeye çalıştı̆̆ı imtiyazla arasında büyük benzerlikler bulunan bu taslağa olumlu bakması, Chester Projesi'ni canlandırmak isteyen çevreleri cesaretlendiren bir faktör olacaktı ${ }^{15}$.

Chester Projesi'nin yeni bir aşamaya geldiği 1922 başlarında, görüldüğü üzere Türk-Amerikan ilișkilerinde bahar havası yaşanıyordu. Gillespie'nin ve Mac Dowell'ın Anadolu'da demiryolu imtiyazları elde etmek amaciyla Ankara Hükümeti nezdinde başlattıkları girişimleri yakından izleyen Fransızlar, Türklerin işgalci emperyalist güçlere karşı sürdürdükleri Ulusal Bağımsızlık Savaşı sırasında ABD ile geliştirdikleri ilişkiler hakkında oldukça ilginç değerlendirmeler yapıyorlardı. Fransızlara göre, Birinci Dünya Savaşı öncesi Türkiye ile ilişkileri Protestanlığı yayma çabasından öteye gitmeyen ve "Vakit" Gazetesi'nin de yazdığı gibi "Türkiye'ye ürünlerinden çok dinini satmaya uğraşan" ABD, ticaret alanında Doğu'da

${ }^{14}$ İsmail Soysal, Tarihleri ve Açıklamaları ile Birlikte Türkiye'nin Siyasal Antlaşmaları, C. I, Ankara, TTK, 1983, s. 51-52. Kilikya, Seyhan (Adana) ve İçel (Mersin) illeri ile Konya ilinin güneyini ve Antalya ilinin doğusunu kapsayan bölgeye verilen addır. Meydan Larousse, C. VII, İstanbul, Meydan Yayınevi, 1972, s. 297. Kilikya demiryolları ile kastedilen, Pozantı'dan başlayarak Yenice, Adana, Ceyhan ve Osmaniye'den geçen demiryolu hattıdır.

${ }^{15}$ Papers Relating to the Foreign Relations of the United States, C. II, Washington, Government Printing Office, 1922, s. 968-970'den Can, s. 218-219, 232. 
ciddi bir kurumsal yapılanma gerçekleştirememişti. Ne var ki Büyük Savaş sonrası ekonomik durumu değişen ABD, Anadolu, İran ve Güney Rusya'da kendisine yeni iş alanları aramak üzere İstanbul'a pek çok şirket temsilcisini göndermişti. Ancak savaş nedeniyle koşulların gittikçe güçleşmesi, krizin ağırlaşması, Anadolu ve Rusya ile yapılan ticaretin sürekli bir durgunluk yaşamasına karşın yine de İstanbul'daki bu Amerikan şirketleri varlıklarını sürdürmeyi başarmışlardı. Halihazırda ise savaşın sona ermesini ve eski ilişkilerin yeniden başlamasını bekleyen bu şirketler, durum normale döner dönmez faaliyete geçmeye hazırlanıyorlardı. Ticareti politikanın temeli olarak gören Türkler ise, Amerikan ticaretinin gelişmesiyle birlikte ABD'nin siyasi anlamda Yakın-Doğu ile ilgilenmek zorunda kalacağına inanıyorlardı. Şöyle ki, Karadeniz'de Amerikan ticaretinin yapılabilmesi açısından Boğazlar'dan serbest geçişin sağlanması, dolayısıyla İstanbul ve Çanakkale Boğazı'ndaki Türk hakimiyetinin sürdürülmesi kaçınılmazdı. Ticari açıdan ilgilendiği ülkelerde ticaret serbestisi ve eşit haklar talep eden $\mathrm{ABD}$, bu nedenle Anadolu'da herhangi bir yabancı devletin üstünlük kurmasına karşı çıkacağı gibi ekonomik nüfuz bölgeleri sorununa da son vermekten kaçınmayacaktı. Dolayısıyla Vakit Gazetesi'nin de belirttiği gibi, YakınDoğu'da gelişen Amerikan ticareti, Türkiye'ye, aynı zamanda görüşlerinin de savunuculuğunu yapacak yeni bir dost kazandırabilirdi. Bunun yanı sıra ülkelerinin yeniden yapılandırılması için mali desteğe ihtiyaç duyan Türklere bu aşamada borç vererek yardım yapabilecek tek ülke ABD idi; zira savaş sonrası Avrupalı devletler de parasal sıkıntı içindeydiler ve yeniden yapılanma çalışmalarının finansmanında yardımına başvuracakları ülke ABD'den başkası olmayacakt ${ }^{16}$.

İşte Fransızlar, Gillespie'nin Ankara seyahatini bu koşulların oluşturduğu bir girişim olarak değerlendiriyorlardı. Onlara göre, İstanbul'daki Amerikan Ticaret Ataşesi, Anadolu'nun genel durumunu (yapılacak çalışmalar, zenginlik kaynakları, Hükümet'in sağlamlık derecesi ve Amerikalı sermayedarlara sağlayacağı güvenceler açısından) incelemek üzere Ankara'ya gitmişti. Gillespie, 1922 başlarında gerçekleştirdiği bu seyahatinde sadece Ankara'ya değil, Konya, Adana ve Mersin'e de gitmiş̧i. Dönüşünde ise, "Amerikan sermayesinin Anadolu'ya hemen girebileceğini" hükümetine bildireceğini açıklamıştı. Gillespie'nin açıklamalarına göre, Amerikalılar Anadolu'da özellikle sulama, maden işletmeciliği alanlarında faaliyet gösterebilecekleri gibi çimento, pamuklu bez, çarşaf fabrikaları kurabilirler, ayrıca tarım aletleri ithalatı da yapabilirlerdi. Ve de halihazırda işe koyulmak için İstanbul'da üç Amerikan şirketinin temsilcisi hazır bekliyordu; bunlardan birisi, güvenceler sağlam olduğu takdirde, demiryolu yapımı için 100 milyon dolarlık yatırım yapmaya hazırdı ve bu çerçevede

\footnotetext{
${ }^{16}$ Château de Vincennes, 7 N 3257, D. 1, "L'Amérique et la Turquie" başlıklı rapor, s.
} 14-15. 
Mac Dowell Anadolu'da girişimlerini başlatmıştı; diğer iki girişimci ise, Chester Şirketi'nin ve petrol devi Standard Oil'in temsilcileriydi ${ }^{19}$.

Yukarıdaki değerlendirmelerden de anlaşılacağı gibi, Türk-Amerikan ilişkilerinin özellikle 1922 başlarında aldığı yeni boyuttan oldukça endişelenen Fransızların tedirginlikleri Mayıs ve Ağustos aylarında daha da artacaktır. Şöyle ki 11 A ğustos 1922 tarihli istihbarat raporuna göre, ABD'nin Ankara temsilcisi Ankara'da bir ekonomik araștırma ve haber bürosu açmaya karar vermişti. Bunun yanı sıra Anadolu'da demiryolu yapımı, maden ve ormanların işletilmesi, geniş arazilerin kullanılması konularında araştırma yapmak üzere ABD'den su, orman ve maden mühendislerinden oluşan 30 kişilik bir Amerikan heyeti Türkiye'ye gelecekti. Ankara Hükümeti ise, kamu yararına çalışmalarda kullanmak amacıyla Amerikalı sermayedarlardan 200 milyon dolarlık bir avans istemişti. Ancak aralarında bir ay önce Ankara'ya gelen ünlü Chester'in de bulunduğu Amerikalı sermayedarların, verecekleri borca teminat olarak Ankara Hükümeti'nden tüm Anadolu limanlarının gelirlerini talep etmeleri söz konusuydu ${ }^{18}$. Dolayısıyla, bir yandan Kilikya demiryolları ve Mersin Limanı'ndaki çıkarlarını tehdit eden bir projeyi Ankara'nın gündemine sokmayı başaran, hatta anlaşma aşamasına gelen Mac Dowell'ın bu kez ailesiyle birlikte Ankara'ya gitmek üzere olduğunu öğrenen Fransızlar ${ }^{19}$, diğer yandan Amerikalıların Anadolu'da bir büro açacak olmalarının tedirginliğini yaşıyorlardı.

İște Anadolu'da Amerikan sermayesi lehine böylesine olumlu bir havanın egemen olduğu dönemde, Amiral Chester Mart 1922'de İstanbul'a gitmek üzere New York'tan ayrılmış, Temmuz 1922'de ise Amerika'ya geri dönmüştü. Bu seyahat sırasında, "bölgenin yeni gücünün Ankara olduğu"nu

\footnotetext{
${ }^{17}$ Aynı rapor, s. 16-17. "Amerika ve Türkiye" başlıklı bu raporda, Gillespie'nin misyonu dışında Mac Dowell'ın Ankara seyahatine de yer verilmiştir. "Cavendish et Fondation" firmasının temsilcisi olan Mac Dowell, ilk olarak 1921 ilkbaharında, , ikinci kez ise 2 Şubat 1922 'de Ankara'ya gelmiş ve aynı gün Mustafa Kemal tarafından kabul edilmişti. Nafia Vekâleti'ne verdiği projede ise, kilometre garantisi istemeksizin İskenderun-Musul ve MusulSamsun demiryollarının yapımı ve demiryolu hattının her iki yanındaki $25 \mathrm{~km}$.lik alanda yer alan madenlerin işletme imtiyazı, ayrıca Samsun Limanı imtiyazı talep ediliyordu. Bunların dışında çalışmalara bir yıl sonra başlanılacağı, şirkette Türklerin istihdam edileceği ve Türk sermayesinin de şirkete ortak olacağı taahhüt ediliyordu. Nafia Vekili ise, 9 Şubat'ta bir açıklama yaparak Amerikan önerilerinin Türkiye'nin ulusal çıkarlarıyla bağdaştığını açıklıyordu. Ancak, kesin anlaşma yapmak konusunda tam yetkili olmayan Mac Dowell, Ankara'daki bu ilk görüşmelerden sonra İstanbul'a dönmüştür. Aynı rapor, s. 17-18. Mac Dowel misyonu ile ilgili olarak Fransız belgelerinde ve Amerikan kaynaklarında yer alan bilgilerin örtüştüğü gözlenmektedir. Görüldüğü gibi, Fransızların haberalma kaynakları oldukça iyi çalışmaktadır. Can, s. 218.

${ }^{18}$ Château de Vincennes, 7 N 3257 , D. 1, "Un bureau d'études américain serait créé en Anatolie" başlıklı, 11.8.1922 tarihli Fransız istihbarat raporu, s. 39.

${ }^{19}$ Château de Vincennes, 7 N 3257 , D. 1, Ankara'dan gelen 2 Mayıs 1922 tarihli telgraflara dayalı, "Les Américains en Anatolie" başlıklı Fransız istihbarat raporu.
} 
iyice kavrayan Chester, Türk yetkililerin kendisine güvendiklerini ve orijinal Chester Projesi'nin kapsadığı bölümü Fransızlara vermediklerini anlamıștı ${ }^{20}$. Kanımızca, Birinci Dünya Savaşı arifesinde yapılan TürkFransız anlaşmasında Fransızlara Kuzey ve Doğu Anadolu ile Suriye'de $2.400 \mathrm{~km}$. lik bir demiryolu şebekesinin yapım hakkı sözü verilmişken ${ }^{21}, 20$ Ekim 1921 tarihli Ankara Anlaşması'nda sadece Pozant1-Nusaybin demiryolu imtiyaz hakkının bir Fransız grubuna verilmesi yolunda bir maddenin yer alması, bunun yanı sıra aynı anlaşmada daha önce 1916 tarihli Sykes-Picot gizli paylaşım anlaşmasında Fransızlara verilmesi kararlaştırılan, ancak şimdi Chester Projesi'nin ilgi alanı içine giren yerlerden (Sivas- Harput- Ergani- Musul- Halep- Yumurtalık'tan) söz edilmemesi ${ }^{22}$ Chester'i rahatlatan temel nedenler olmalıdır. Çünkü böylece bölgede olası Fransız ve Amerikan çıkar çatışmasından uzaklaşılmış olunuyordu.

Amiral Chester'in 26 Mart'ta Türkiye'ye hareketinden birkaç hafta sonra oğlu Arthur Chester yola çıkmıştı. Eylül ortalarında ise Clayton-Kennedy ve Arthur Chester, aralarındaki yetki kavgasına karşın Ankara'ya gidiyorlardı. Görevleri, 1909'da Osmanlı makamlarına sunulmuş olan Chester Projesi'ni bu kez Ankara Hükümeti'nin gündemine getirmek ve onlarla bir anlaşma yapmakt1 ${ }^{23}$.

\section{Chester Projesi'nin Ankara'nın Gündemine Girmesi}

Amiral Chester ve oğlunun İstanbul'da bulundukları 1922 yazı son derece kritik bir dönem özelliği taşıyordu. Büyük Taarruz öncesi Ankara Hükümeti'nin Avrupa başkentlerinde diplomatik temas ve zemin yoklamalarını sürdürdüğ̈̈ bir dönemde Fransızlar, bir yandan Haziran ayında Ankara'ya gönderdikleri Albay Mougin kanalıyla Anadolu'daki siyasi ve askeri gelişmeleri dikkatle izlerlerken ${ }^{24}$ diğer yandan Ankara'ya

${ }^{20}$ Can, s. 236.

${ }^{21}$ Ministère des Affaires Etrangères (Fransız Dışişleri Bakanlığı Arşivi, bundan sonra MAE), Série E Levant Turquie, Vol. 169, 23 Mayıs 1919 tarihli gizli memorandum, s. 67-68. Selim İlkin'in araştırmasında ise, 1914 yılında Cavit Bey'in Fransa'dan sağladığı kredi karşılığında Fransızlara Sivas-Samsun demiryolu yapım hakkı sözünün verildiği ve bir Fransız grubunun hemen çalışmaya koyulduğu, ancak savaşın patlak vermesi üzerine işi bıraktıkları belirtilmektedir. İlkin, Türkiye Iş Bankası Uluslararası Atatürk Sempozyumu: Bildiriler ve Tartışmalar, s.777 n 76.

2220 Ekim 1921 tarihli Ankara Anlaşması'nın esas metni ve ek mektupları için bkz. Soysal, C. I, s. 50-59.

${ }^{23}$ Can, s. 237.

${ }^{24} 8$ Haziran 1922'de Ankara'ya gelen ve üç yıl boyunca burada görev yapan Fransa'nın Ankara Hükümeti nezdindeki ilk temsilcisi Albay Mougin'in Ankara'daki faaliyetleri hakkında detaylı bilgi için bkz. Paul Dumont, "A l'aube du rapprochement franco-turc: premier représentant de la France auprès du gouvernement d'Ankara," La Turquie et la France à l'époque d'Atatürk, C.I, Paris, Association pour le développement des études turques, 1981, s. 75-108. 
savaș malzemesi yardımı yapıyorlard ${ }^{25}$. Ancak böylesine kritik ve hareketli bir dönemde yine de Chester Projesi'ni izlemeyi ihmal etmiyorlardı. Fransızlar, Amiral Chester ve oğlunun İstanbul'da bulundukları günlerde hazırladıkları bir raporda Chester Projesi'ni başlangıcından itibaren mercek altına alıyorlardı. Fransızlara göre, 1910 yılında Amerikalı sermayedarların Osmanlı Hükümeti nezdindeki etkin girişimlerinin hedefi olan, ancak sonuçlandırılamayan bu projede üç hattın yapımı öngörülüyordu. Birinci hat, Sivas'tan başlayarak Keban Maden, Harput, Palu, Muş ve Bitlis üzerinden Van'a gidecek, Keban Maden'den önce ise bir yan hatla Malatya'ya bağlanacaktı. Bu hattın toplam uzunluğu 850 kilometre olarak hesaplanmıştı. Ancak projede bir değişiklik yapılarak Diyarbakır'dan Bitlis'e bir hat döşenmesine karar verilmişti. İkinci hat, Harput'tan başlayarak Diyarbakır, Cizre, Musul, Kerkük üzerinden Süleymaniye'ye ulaşacak ve yaklaşık 900 km uzunluğunda olacaktı. Üçüncü hat ise, Keban Maden'in doğusunda bir noktadan başlayacak ve Malatya Ovası'ndan geçerek Elbistan, Maraş üzerinden İskenderun Körfezi'nde Yumurtalık'a ulaşacak ve yaklaşı 350 $\mathrm{km}$ uzunluğunda olacaktı ${ }^{26}$.

Fransız raporunda, ayrıca, Sivas'ın birinci projede hattın başlangıç noktası olarak belirlendiği, Morgan grubu adına hareket eden M. Carter'in 1912 'de sunduğu değiștirilmiş projede ise Sivas yerine Harput'un öngörüldüğü, ancak 9 Nisan 1914 tarihli Türk-Fransız anlaşmasında SivasHarput hattının 2.344 km uzunluğundaki Karadeniz demiryolu şebekesindeki Fransız nüfuz bölgesinde yer aldığı ve bu şebekenin çeşitli yan hatlarla birlikte Samsun-Sivas, Sivas-Harput, Sivas-Erzurum ve Erzurum-Trabzon hatlarından oluştuğu belirtiliyordu. Bunun yanı sıra Chester ile Ankara Hükümeti arasında başlayan görüşmelerin hangi aşamada olduğu hakkında bilgi almanın mümkün olmadı̆̆ı, ancak İstanbul'dan "Chester'in arkasında kimsenin bulunmadığı ve de projesinin spekülasyondan öteye gidemeyeceği”" yolunda Amerikan kaynaklı bir haber aldıkları vurgulanıyor ve bir yandan Chester Projesi'nin Birinci Dünya Savaşı öncesi Morgan tarafından yeniden ele alınmış olduğuna diğer yandan Anadolu'da demiryolu yapımına acil olarak ihtiyaç duyulmadığına dikkat çekilerek, bu nedenlerden ötürü haberin akla yatkın olduğu yolunda yorum yapılıyordu ${ }^{27}$. Chester Projesi'nin

${ }^{25}$ Mart 1922'de Paris'e gönderilen Dıșişleri Bakanı Yusuf Kemal Bey'in Fransa'da yaptığı görüşmeler sonunda Büyük Taarruz öncesi Haziran ve Temmuz aylarında savaş malzemeleri Türk ordusuna teslim edildi. Salâhi R. Sonyel, Türk Kurtuluş Savaşı ve Dış Politika, C.II, Ankara, TTK, 1986, s. 205-206.

${ }^{26}$ Château de Vincennes, 7 N 3257 , D. 1, "Etude sur les projets de chemin de fer en Anatolie" başlıklı rapor.

${ }^{27}$ Aynı rapor. Chester Projesi'ne şüpheyle bakanlar arasında Almanlar da vardı. Alman Genelkurmay Başkanı ve Demiryolları Kumandanı Major Kübel, Birinci Dünya Savaşı öncesi kaleme aldığı raporunda, Chester'in Yumurtalık'tan başlayarak İskenderun üzerinden Mezopotamya' $y_{1}$ bir uçtan diğer uca geçecek bir demiryolu hattı boyunca bölgedeki petrollerin işletilmesini Amerikan tasarrufuna sokacak projesini oldukça hayalci buluyordu. 
geleceği konusundaki bu olumsuz değerlendirmelere karşın projenin gerçekleşebileceğine inananlar da bulunuyordu. İstanbul'da görev yapan Fransız Yüksek Komiseri Pellé, 15-16 Ekim 1922 tarihli telgraflarında, Chester Projesi'nin başarı şansının bulunduğunun kendisine açıkça söylendiğini, zira Chester'in temsil ettiği grubun Ankara Hükümeti'ne maden ve petrol teminatı karşılığında borç vermeyi önerdiğini Paris'e bildiriyordu ${ }^{28}$. Aynı tarihlerde ise Ankara, Chester Projesi'nin geleceği açısından önemli gelişmelere sahne oluyordu. Eylül ortalarında Ankara'ya gelen Arthur Chester ve Kennedy, projeyi TBMM Hükümeti yetkilileriyle görüşmeye başliyorlar ve bu görüşmeler çerçevesinde yirmi gün gibi kısa bir süre içinde esaslar üzerinde ön anlaşmaya varılıyordu. TBMM Hükümeti, ayrıca, 88.000 dolardan 30.000 dolara indirdiği teminat yatırıldığı takdirde projeyi hemen Meclis'e göndermeyi kabul ediyordu ${ }^{29}$. Bu arada şirket içindeki uyușmazlıklara karșın yine de Ankara'daki temaslarını sürdürmeyi başaran ikiliden Clayton-Kennedy Eylül sonuna kadar devam eden görüsmelerden sonra İstanbul'a dönüyor, Arthur Chester ise Ankara'da kalıyordu. Ancak ABD Dışişleri Bakanlığı, Kennedy sayesinde haberdar oldukları Ankara tarafından talep edilen teminat parasını şirkete duyduğu güvensizlik nedeniyle hemen yatırmıyor ve bir süre beklemeyi yeğliyordu ${ }^{30}$.

Fransa'nın Ankara'daki temsilcisi Albay Mougin ise, Chester Projesi ile ilgili gelişmeleri hükümetine bildirmeyi ihmal etmiyordu. Şöyle ki 26 Ekim 1922 tarihli telgrafında, Fethi Bey'den Chester Projesi'nin halihazırda ilgili bakanlıklarca incelenmekte olduğunu öğrendiğini ve kilometre garantisi verilmeksizin Samsun- Trabzon- Erzurum- Van- Musul- Diyarbakır- AyasKayseri-Ankara güzergâhında 2.500 kilometrelik bir demiryolu şebekesinin yapım imtiyazını içeren projenin, ayrıca yapımcı şirkete demiryolu hattının sağında ve solundaki 20 'şer km.lik alanda bulunan tüm madenlerin imtiyazını verdiğini bildiriyordu. Mougin, bunun yanı sıra Fethi Bey'in Chester'den Fransız gruplarla anlaşmasını istedigini, zira Türkiye'nin Fransa'yı göz ardı edemeyeceğini, Chester'in ise Fethi Bey'in bu önerisine sıcak baktığını, kendisinin ise Fethi Bey'e Samsun-Sivas-Harput demiryolu imtiyazının daha önce bir Fransız grubuna verildiğini hatırlattığını, bunun üzerine ondan bu hatla ilgili halihazırda hiçbir çalışma yapılmadı̆̆ı, dolayısıyla Fransız grubun elde etmiş olduğu ayrıcalıktan vazgeçmiş gibi bir

Ünsal Yavuz, "Cumhuriyet Devri Demiryolu Politikasına Yaklaşım Biçimi,” IX. Türk Tarih Kongresi, Ankara, TTK, 1989, s. 1645.

${ }^{28}$ MAE, Série Relations Commerciales, B. 48, Vol. 50, Pellé'nin İstanbul, 15.10.1922 tarihli telgrafı, s.74; Château de Vincennes, 7 N 3257, D. 1, Pellé'nin İstanbul, 16.10 .1922 tarihli telgrafı. Ankara Hükümeti ile (yarı) resmi ilişkiler başlatma kararı veren ABD'nin Haziran 1922 'de temsilci olarak Ankara'ya gönderdiği Imbre, ABD Dışişleri'ne yazdığı raporda Chester Grubu temsilcilerinin büyük olasılıkla Ankara Hükümeti ile bir anlaşma imzalayabileceklerini bildirmiști. Can, s. 236-237.

${ }^{29}$ İlkin, Türkiye Işs Bankası Uluslararası Atatürk Sempozyumu: Bildiriler ve Tartışmalar, s.749.

${ }^{30}$ Can, s. 238-239. 
görünüm sergilediği yolunda yanıt aldığını hükümetine rapor ediyordu ${ }^{31}$. Albay Mougin'in Chester Projesi'nin son durumu ile ilgili bilgi verdiği günlerde Fransızlara, ayrıca, Chester'in temsil ettiği Amerikan grubu adına Anadolu'daki tüm demiryolu şirketlerini satın almak istediği yolunda haberler de geliyordu ${ }^{32}$. Ancak Chester Projesi ve Anadolu'daki demiryolu imtiyazları ile ilgili istihbarat raporlarının yoğunluğuna karşın Fransız Ticaret ve Sanayi Bakanlığı bünyesinde yer alan Petrol ve Benzin Dairesi'ne gelen haberler hiç de göz ardı edilecek gibi değildi.

4 Kasım 1922 tarihli Washington kaynaklı haberlere dayanılarak hazırlanan "Amiral Chester İmtiyazı Onaylandı" başlıklı yazıda, Türk Hükümeti'nin Amiral Colby M. Chester'in 1909'da elde ettiği imtiyazı yenilediği ve onayladığı, bunun da ötesinde Chester'i haklarının hiçbir şekilde tartışılmasına imkân vermeyecek bir konuma getirmek için her türlü önlemi aldığ 1 , aslında Amiral'in haklarının daha önce güvence altına alındığı, öyle ki Chester'in elde ettiği ilk imtiyazda savaş nedeniyle imtiyaz anlaşmasındaki koşulların yerine getirilememesi durumunda kendisine tanınan hakların askıda tutulacağ maddenin bulunduğu, dolayısıyla Türklerin şimdiye kadar çeşitli savaşlara girmiş olmaları nedeniyle ön inceleme çalışmalarının yapılabilmesi ve jeolojik yapının araştırılabilmesi için hemen gerekli önlemlerin alınacağı bildiriliyordu. Yazıda, ayrıca, yaklaşık 1.200 mil uzunluğunda bir demiryolu şebekesinin yapımını öngören, Bağdat Demiryolu'nun İran sınırına kadar uzatılmasını ve Türkiye'nin belli başlı şehirlerinin demiryollarıyla birbirine bağlanmasını amaçlayan bu projenin aynı zamanda 20 yıldır pek çok çıkar grubunun ilgi alanı olan Musul bölgesindeki petrol imtiyazlarını içerdiği ve Birinci Dünya Savaşı öncesi imtiyazın gerektirdiği araştırmaların çoğunun yapıldığı ve petrol yataklarının genel olarak nerede yer aldığının belirlendiği vurgulanıyordu. Bunun yanı sıra Chester Projesi'nin hangi koşullarda onaylandığının Fransız Hükümeti'nin ilgili birimlerince iyi bilindiğine dikkat çekilerek, Amiral Chester'in Roosevelt'in başkanlığı döneminde 1899 'da İstanbul'a yaptığı ilk seyahatten başlayarak Chester Projesi'nin tarihsel gelişimi anlatılıyor ve padişah tarafından kendisine ilk kez 1908'de Osmanlı İmparatorluğu'nda çeşitli bayındırlık işlerini içeren geniş bir imtiyaz önerilen Chester'in demiryolu imtiyazı çerçevesinde üç şirket kurduğu, birincisinin "Ottoman American Development Co.", ikincisi "Ottoman American Industrial Co.", üçüncüsünün ise "Ottoman American Petroleum Co." olduğu belirtiliyordu. Yazıda Chester Projesi hakkında ilginç bir değerlendirme de yapılıyordu. Şöyle ki, demiryolu yapımı ve

\footnotetext{
${ }^{31}$ Château de Vincennes, 7 N 3257 , D. 1, Mougin'in Ankara, 26.10 .1922 tarihli telgrafını Fransız Dışişleri Bakanlı̆̆ı'na ileten Pellé'nin İstanbul, 30.10 .1922 tarihli telgrafı. Albay Mougin'in bilgi aldığı kişi, 12 Temmuz 1922'de göreve başlayan kabinede Dahiliye Vekili olarak görev alan Ali Fethi (Okyar) Bey olmahdır.

${ }^{32}$ Château de Vincennes, 7 N 3257 , D. 1, Bern kaynaklı, "Concessions ferroviaires en Anatolie" başlıklı 30.10.1922 tarihli Fransız istihbarat raporu.
} 
Mezopotamya petrol yataklarının işletilmesi, imtiyaz sahiplerine sağlayacağı büyük kârlardan çok ABD ekonomisine yapacağı katkılar açısından yadsınamaz bir öneme sahiptir. Zira bu projeler, ABD'den büyük çapta delme, arıtma ve demiryolu araç-gereçleri ile tekerlekli taşıtların satın alınmasını beraberinde getirecektir ${ }^{33}$.

Yukarıdaki bilgilerin ışı̆̆ında, Fransızların, Chester Projesi'nin tarihsel gelişimi hakkında oldukça sağlıklı verilere sahip oldukları söylenebilir ${ }^{34}$. Ancak projenin tarihsel boyutunun yanı sıra güncel gelişmeler hakkında daha detaylı bilgi almak isteyen Fransız yetkilileri, özellikle Amiral Chester'in Ankara'da bulunan ve projenin son 15 yıllık serüveninden haberdar olan Türk siyasi ve mali çevrelerinin desteğini kazanmış olan oğlu Arthur I Chester'in girişimlerine karşı son derece duyarlıydılar. Bunun da ötesinde imtiyazı kullanacak şirketlerin büyük oranda kurulmuş olması, Türkiye'nin kalkınmasında Amerikan şirketlerinin oynayacağı önemli rolü göstermesi açısından Fransızların moralini bozuyordu ${ }^{35}$. Bern'den gelen 14 Kasım tarihli istihbarat raporu, Fransızların moralini daha da bozan bilgiler içeriyordu. Şöyle ki İktisat Vekili Mahmut Esat (Bozkurt) Bey, İsviçre'deki Türk milliyetçilerinin başı konumundaki Harun (Aliçe) Bey'e Ankara Hükümeti'nin Amerikalı Chester'e önemli demiryolu imtiyazları verme konusunda kararlı olduğunu ve öneminin herkesçe iyi bilindiği TrabzonErzurum hattının da bu demiryolu imtiyazları içinde yer aldığını bildiriyordu ${ }^{36}$. Lozan Barış Konferansı'na ikinci temsilci olarak seçilen eski Maliye Vekili Hasan (Saka) Bey ise, Lozan'a hareket etmeden önce verdiği demeçte, Chester' in daha önceki hükümetlere yaptığı önerilere yeni bir şekil verdiğini, ne var ki kendisi artık hükümette olmadığı için yeni düzenlenmiş projede yer alan ana hatlar konusunda kesin bilgi sahibi olmadığını, ancak Ankara'da Chester Projesi ile ilgili görüşmelerin devam etmekte olduğunu, şayet söz konusu proje Türk çıkarlarına uygun bir hale getirilirse hükümetin projenin yeni şeklini inceleyip daha sonra Büyük Millet Meclisi'nin onayına sunacağını, ancak ülkenin doğal zenginliklerinin değerlendirilmesi

${ }^{33}$ MAE, Série Relations Commerciales, B. 48, Vol. 50, 9.11.1922 tarihli Oil \& Gaz Journal'de yer alan "La Concession de l'Amiral Chester est confirmée" başlıklı yazı, s. 81-83. Bilmez Bülent Can'ın Chester Projesi üzerine Almanya'da yapılan çalışmalardan aktardığı bilgilere göre, Chester imtiyazlarını gerçekleştirmek üzere çeşitli şirketler kurulmuştu. Bu şirketler yukarıdaki Fransız belgesinde belirtilenlerle aynıdır, yani Ottoman-American Development Co., Ottoman-American Industrial Co. ve Ottoman-American Petroleum Co. dir.

34 Örneğin, Chester'den çok hoşlanan II. Abdülhamid'in Chester'e "Osmanlı İmparatorluğu'ndaki bütün bayındırlık işlerini alın ve bunları sizce bu işler için en uygun müteahhitlere dağıtın..."dediği çeşitli kaynaklarda yer almaktadır. Tezel, AÜ Siyasal Bilgiler Fakültesi Dergisi, C. XXV, No. 4 (Aralık 1970), s. 290.

${ }^{35}$ MAE, Série Relations Commerciales, B. 48, Vol. 50,9.11.1922 tarihli yazı, s.83, 87.

${ }^{36}$ Château de Vincennes, 7 N 3257, D. 1, Bern, 14.11.1922 tarihli, "Les transactions entre Nationalistes turcs et Américains au sujet des Chemins de Fer" başlıklı Fransız istihbarat raporu. 
ve kalkınmasının sağlanması için Türkiye'de yeterince yerli sermaye bulunmadığının bilincinde olduklarını açıklıyordu ${ }^{37}$. Hasan Bey'in projenin son durumu hakkında demeç verdiği tarihlerde Amiral Chester ve ortakları da, demiryolu, maden ve petrol imtiyazlarının Musul"daki petrol alanlarının arasından geçtiğini, ancak Türk parlamentosunun henüz projeyi onaylamadığını açıklıyorlardı ${ }^{38}$.

İşte böylesine bir açıklama trafiğinin sürdüğü tarihlerde, Arthur Chester İstanbul'a dönmek zorunda kalıyordu; zira Ankara Hükümeti'nin İngiliz ajanı olmasından kuşkulandığı Clayton-Kennedy'nin Kasım başlarında izinsiz olarak Anadolu'ya geçmek istemesi üzerine tutuklanması, Arthur Chester'in sorunu çözmek üzere İstanbul'a dönmesine neden olacaktı. Ancak tam anlaşmanın imzalanmasının beklendiği sırada Clayton-Kennedy hakkındaki söylentilerin kamuoyuna yansıması Ankara'da Chester Projesi'ne karşı kuşku duyulmasına neden oluyordu. Aralık ortasında Clayton-Kennedy'e Anadolu'ya geçme izni verilince, Arthur Chester ve Clayton-Kennedy Ankara'ya dönerek görüşmelere kaldıkları yerden devam ettiler $^{39}$.

14 Aralık 1922'de Ankara'ya dönen Chester'in Ankara Hükümeti'nin projesini tekrar ele almasını sağlamaya çalıştığı günlerde Albay Mougin de, Paris'e gönderdiği telgrafta, Chester'in amacına ulaşabileceğini, zira Ankara'da yöneticilerin, özellikle Rauf Bey, Fethi Bey ve Ali Fuad Paşa'nın Türkiye'nin ekonomik açıdan kalkınabilmesi için ihtiyaç duyduğu sermayeye yalnızca ABD'nin sahip olduğuna inandıklarını bildiriyordu ${ }^{40}$. Halbuki 16 Aralık 1922 tarihli bir Fransız istihbarat raporunda, Lozan'a giden Türk heyetinde yer alan pek çok kişinin, özellikle danışman olarak görev yapan Muhtar Bey'in Chester'in sunduğu projelerin başarı şansının bulunmadığına, dolayısıyla sonuca ulaşamayacağına inandığı vurgulanıyordu ${ }^{41}$. Dolayısıyla Chester Projesi'nin başarı şansı konusunda

${ }^{37}$ Château de Vincennes, 7 N 3257, D. 1, 11.11.1922 tarihli "Stamboul" Gazetesi kaynaklı, 17.11.1922 tarihli "Les projets Chester" başlıklı Fransız istihbarat raporu, s. 49.

${ }^{38}$ MAE, Série Relations Commerciales, B- Produits du sol, Vol. 50, Fransız Ticaret ve Sanayi Bakanlığı Benzin ve Petrol Dairesi'nin hazırladığı "La question pétrolière turque n'est pas grave au point de vue des USA" başlıklı, 20.11.1922 tarihli rapor, s. 125-126.

${ }^{39}$ Can, s. 241-243.

${ }^{40}$ MAE, Série Relations Commerciales, B- Produits du sol, Vol. 50, Pétroles de Mésopotamie, Mougin'in 16.12.1922 tarihli telgrafını ileten Jesse-Curely'nin Fransız Dışişleri Bakanlığı'na gönderdiği 16.12.1922. Dönemin Başbakanı Rauf Bey, 8 Nisan 1923 günü Büyük Millet Meclisi'nde yaptığı konuşmada Chester Projesi'ni barıştan sonra ulusun sonsuza dek kurtuluşunu sağlayacak esaslardan biri olarak değerlendirmiştir. Tezel, $A \ddot{U}$ Siyasal Bilgiler Fakültesi Dergisi, C. XXV, No. 4 (Aralık 1970), s. 304.

${ }^{41}$ Château de Vincennes, 7 N 3257 , D. 1, 16.12.1922 tarihli, "La question des chemins de fer d'Anatolie " başlıklı Fransız istihbarat raporu. Muhtar (Çilli) Bey, Lozan Konferansı'na katıldığı sırada Bayındırlık Bakanlığı Müsteşarı idi. Dışişleri Bakanlığı Araştırma ve Siyaset Planlama Genel Müdürlüğü, Türkiye Dış Politikasında 50 Yll: Lozan (1922-1923), Ankara, 1973 , s. 5 . 
gelen bu çelişkili bilgilerin, başından beri bu projeden rahatsız olan Fransızların Lozan Barış Konferansı'nın başladığı dönemde tedirginliklerinin devam etmesine neden olduğu söylenebilir.

\section{Lozan Barış Konferansı ve Chester Projesi Sorunu}

İtilaf Devletleri, Birinci Dünya Savaşı'ndan sonra Mustafa Kemal Paşa'nın önderliğinde tek başına kendilerine karşı koyan, topraklarını işgal eden emperyalist güçlere karşı verdiği Ulusal Bağımsızlık Savaşı ile Sèvres Barış Antlaşması'nın yürürlüğe konmasını engelleyen yeni Türk Devleti ile yüzyıllık sorunlarını tartışmak üzere 20 Kasım 1922'de Lozan'da bir araya geliyorlard1.

Musul Sorunu, Lozan Barış Konferansı'nda Anglo-Sakson çevrelerin en çok ilgilendikleri konuların başında geliyordu. Lozan'da tartışılan Boğazlar, azınlık hakları gibi siyasal sorunlar ise, büyük ilgi odağı olan petrol sorununun neden olduğu şiddetli kavgayı gizlemeye yönelik aldatıcı bir dış görünüştü ${ }^{42}$.

"Lozan 'Procès verbal'lerinin en meraklı safhası, Musul çarpışmasıdır. Türkiye'nin Irak sinırını çizecek olan dâva, tartışmasının şekli yüzünden, bütün dünyanın ilgi gösterebilece ği kadar önem kazanmıştır. Bu yaman bir söz, zekâ, akıl, mantık ve hazır cevaplılık güreşidir. Daha doğrusu iki tarafın var kuvvetiyle birbirini yenmeye çalıştı̆̆ı bir çeşit 'siyasal pankreas'tır..."

İşte Ali Naci Karacan'ın "siyasal pankreas" benzetmesi yapmasına neden olan Lozan Konferansı öncesi İngiliz kabinesi Dışişleri Bakanı Lord Curzon'a “...Türk heyetinin Musul'un Türkiye'nin sınırları içine dahil edilmesi yönünde ileri sürebileceği öneriyi, diğer gerekçelerin yanında adı geçen vilayetin Irak Krallığına ait olduğunu belirterek hiçbir şekilde tartışmayı kabul etmemesi..." talimatını verirken, Türk Dışişleri Bakanı İsmet Paşa ise konferansa şu talimatla katılıyordu: "Süleymaniye, Kerkük ve Musul livaları istenecek, konferansta başka bir durum ortaya çıkarsa talimat alınacaktır." Konferansın toplandığı dönemde Musul petrolleri sahnesinde önemli bir rol kapma savaşımı veren $\mathrm{ABD}$ ise, buna karşın Lozan Konferansı'na sadece gözlemci olarak katılıyordu. Konferans öncesi ABD'de Mezopotamya petrol sahnesinde yer almak isteyen ve bu çerçevede Amerikan Dışişleri Bakanlığı'nın siyasal desteğini talep eden üç çıkar grubu vardı: Turkish Petroleum Company'le ortaklık görüşmelerini sürdürmekte olan büyük Amerikan petrol şirketleri, Amiral Chester'in Ottoman-American

${ }^{42}$ MAE, Série Relations Commerciales 1919-1940, B. 48, Vol. 50, Fransız Dışişleri Bakanlığı Ticari ve Politik İşler Müdürlüğü tarafından Mezopotamya petrolleri hakkında hazırlanmıs 24.11.1922 tarihli bilgi notu, s. 95 .

${ }^{43}$ Ali Naci Karacan, Lozan, 2. B., İstanbul, Milliyet Yayınlan, 1971, s. 242. 
Development Company'si ve II. Abdülhamid'in mirasçıları adına Samuel Untermyer ve Ortaklari ${ }^{44}$.

Lozan müzakerelerinin resmi oturumlar ve ikili görüşmeler şeklinde yoğun bir şekilde devam ettiği günlerde İsmet Paşa, Abdülhamid'in mirasçılarını temsil eden Amerikalı işadamı Untermyer'ı kabul ediyor ve onun önerilerini hem Ankara'ya iletiyor hem de destekliyordu. Untermyer, Abdülhamid'in kişisel mal varlığının büyük bölümünün Türkiye dışında kalması nedeniyle hem mirasçılarının hem de devletin bu emlak üzerindeki haklarının zarar gördüğ ünü savunuyor, dolayısıyla yalnız mirasçıların hakkını korumak değil, Türk Hükümeti'ne de pay sağlamak istiyordu. Şöyle ki, şayet Türk Hükümeti mirasçıların daha önce Şer'i Mahkeme tarafından kabul edilen haklarını onaylarsaTürk uyruğu olmaları nedeniyle mirasçılar söz konusu mal varlı̆̆ına resmen sahip olmuş olacaklar, Amerikan grubu ise bu durumda Türk Hükümeti'ne hem gelir üzerinden bir pay hem de hisse senetlerinin önemli bir kısmını verecektir. Böylece petrol alanlarından, bir kısmı Türk egemenliğinden çıksa bile, bazı Türk uyruklular yararlanmıș olacaktır. İsmet Paşa'ya göre, Untermyer'ın önerdiği bu çözüm yolu benimsenirse -her ne kadar kesin bir söz verilemez ise de- Amerikan Hükümeti'nin Musul konusunda Türkiye lehine ağırlı̆̆ını koyması olasılığı vardır. İsmet Paşa'nın Chester Projesi konusundaki düşünceleri ise şöyleydi:

${ }^{44}$ Hikmet Uluğbay, Imparatorluktan Cumhuriyete Petropolitik, Ankara, Turkish Daily News Yayınları, 1995, s. 182-183. 1912'de kurulan, hisselerinin büyük kısmı İngilizlere ait olan Turkish Petroleum Co.'ye Haziran 1914'te Alman ve İngiliz baskıları sonucu Musul ve Bağdat'ta petrol arama imtiyazının verilmesi kararlaştırılmış, ne var ki araya giren savaş nedeniyle anlaşma imzalanamamıştı. 24 Nisan 1920'de Fransa ile İngiltere arasında imzalanan San Remo Petrol Anlaşması'yla ise, Almanların şirketteki \%25 hissesi Fransızlara devredilmişti. André Nouschi, Luttes pétrolières au Proche-Orient, Paris, Ed. Flammarion, 1970, s. 30-32; MAE, Série Relations Commerciales 1919-1940, B. 48, Vol. 49, s. 8-11; İlkin, Türkiye Iş Bankast Uluslararası Atatürk Sempozyumu: Bildiriler ve Tartışmalar, s.748. II. Abdülhamid, 1890 ve 1899 yıllarında Musul ve Bağdat vilayetlerindeki petrol imtiyazlarını Hazine-i Hassa'ya kaydırmıs, ancak Hazine-i Hassa bu imtiyazlanı bazı koşullarla "AnadoluBağdat Osmanlı Demiryolları Şirketi”ne devretmişti. Nouschi, s. 17-19. 1908'de II. Meşrutiyet'in ilanından sonra ise, Abdülhamid'in özel mal varlığındaki Musul ve Bağdat petrol alanları Maliye Nezareti'ne bağlanmıştı. Petro-Strateji, İstanbul, Harp Akademileri Komutanlığı Yay., 1996, s. 31. 1921 başlarında, Abdülhamid'in 32 mirasçısının ortak olduğu Hirsch Ltd. ve Central Mining and Investment Co. kurulmuş ve bu şirketler adına Albay Edwards, 1921 Martı'nda İngiliz Dışişleri Bakanlığı'na başvurarak Mezopotamya petrollerinin Abdülhamid'in özel mülkü arasında olduğunu, İttihat ve Terakki Hükümeti'nin kararının geçersiz olduğunu savunmuş ve mirasçıların hakkının tanınmasını talep etmişti; ayrıca özel mülkiyete ait olan bu petrol yataklarının Müttefik devletler arasında paylaşılamayacağını ileri sürmüştü. Ancak mirasçılar, İngiltere Dışişleri Bakanlığı'ndan aradıklanı desteği bulamayınca ABD'yi devreye sokmaya çalışmışlardır. Uluğbay, s. 167-168. İlkin ise, araștırmasında, Musul ve Bağdat petrollerinin işletme hakkının kendilerine ait olduğunu iddia eden, hatta bu konuda Şeyhülislam'dan fetva alan Abdülhamid'in kişisel mirasçılarının oluşturduğu Ottoman Imperial Estate adlı bir şirketten söz etmektedir. İlkin. Türkiye Iș Bankası Uluslararası Atatürk Sempozyumu: Bildiriler ve Tartışmalar, s.748. 
O, bu projenin Fransızlarla yapılan anlaşmaya aykırı olduğunu, zira aynı imtiyazın daha önce Fransızlara verildiği yolunda kendisine haber geldiğini, bu nedenle Fransızları tahrik etmemek ve Amerikalıları küstürmemek için Chester Projesi'ne ilişkin imtiyaz işlemlerinin geciktirilmesinin uygun olacağını düşünüyordu ${ }^{45}$.

Başbakan Rauf Bey ise, Chester Projesi'nin daha önce Fransızlara verilmiş imtiyazla çatıştığı yönündeki görüşlerin aydınlatılması amacıyla İsmet Paşa'nın gönderdiği 30 Aralık 1922 tarihli telgrafa verdiği yanıtta, Samsun-Sivas demiryolu yapımının Padişah emri ile 1912 yılı devlet borçlanmasına bağımlı olarak Régie Genérale des Chemins de Fer şirketine verildiğini, ancak bu konuda kesin bir sözleşme imzalanmadan Dünya Savaşı çıktığından iznin Bakanlar Kurulu'nca "verilmemiş" kabul edildiğini, bunun üzerine Fransız şirketinin bu durumu protesto ettiğini, Chester şirketi ile Doğu Anadolu'da demiryolu yapımı ve işletilmesi konusunda Ankara'da sürdürülen görüşmelerde ise bu ihtilaflı durumun göz ardı edilmediğini ve gerektiğinde Fransız şirketine ödenecek tazminatın söz konusu edilerek sözleşme eklerine kaydedildiğini, ancak ulusal çıkarlar açısından Chester ve ortağı ile görüşmelerin sürdürülmesinin daha uygun bulunduğunu ve de görüşmelere Nafia Vekaleti'nce devam edileceğini bildiriyordu ${ }^{46}$.

Lozan görüşmeleri sırasında Chester Projesi ile ilgili bu tartışmalar sürerken Türkiye açısından gelişmeler beklenildiği gibi olmadı. 1922 sonbaharında Chester ile esaslar üzerinde ön anlaşmaya varan Türk yöneticileri, Lozan'da bu proje dolayısıyla ABD desteğini sağlayarak bunu özellikle İngiltere ve Fransa'ya karşı kullanmak, bir başka deyişle barış konteransında kısmen de olsa yalnızlıktan kurtulmak istiyorlardı. Amaçları, Mondros Ateşkes Anlaşması sonrası İngiliz işgali altına giren ve gerek Turkish Petroleum Company'nin gerekse Abdülhamid'in varislerinin petrol rezerv ve işletmeleri üzerinde hak iddia ettikleri Musul'un tekrar Türkiye sınırları içine dahil edilmesinde ve bu iddiaların reddinde Amerikan desteğine sahip olmaktı ${ }^{47}$. Ne var ki Türkiye, Lozan Konferansı öncesi Amerikan sermayedarlarıyla anlaşmasına karşın konferansta ABD'den beklediği desteği bulamadı. ABD'nin Türkiye'nin Musul politikasına destek vermeyişinde dev Amerikan şirketlerinin çıkarlarının rol oynadığı söylenebilir. Zira Mezopotamya petrollerinden pay almak için Turkish Petroleum Co.'den hisse almaya çalışan Standard Oil of New Jersey'in özellikle 1922 yazından itibaren bu amaçla verdiği mücadele hiç de göz ardı edilecek türden değildi. Mezopotamya petrollerinin işletilmesine katılabilmek için 1922 Temmuzu'ndan itibaren İngiliz ve Fransızlarla pazarlık masasına oturan Amerikan petrol devi Standard Oil Co., 1922

\footnotetext{
${ }^{45}$ Uluğbay, s. 198-199.

${ }^{46}$ A. g.e., s. 201-202.

${ }^{47}$ Illkin, Türkiye İ̧ Bankası Uluslararası Atatürk Sempozyumu: Bildiriler ve Tartışmalar, s. $750-751$.
} 
Kasımı'na gelindiğinde Turkish Petroleum Co.'ye ortaklığı konusunda belli bir mesafe katetmiş ve Amerikalıların katılımıyla ilgili düzenlemelerin İngiliz ve Fransız hükümetlerinin işbirliği ile tamamlanmak üzere olduğu yönünde haberler Amerikan basınında yer almaya başlamışst ${ }^{48}$.

Standard Oil gibi dev bir Amerikan petrol şirketinin Mezopotamya petrol alanlarında söz sahibi olmak amacıyla başlattığı girişimlerin Lozan barış görüşmeleri öncesi geldiği aşama, ABD'nin Lozan'da izleyeceği politika konusunda önemli ipuçları vermektedir. Şöyle ki, ABD'nin Türkiye'nin Musul tezine destek vermesi ve de Musul bölgesinin Türkiye'ye bırakılması durumunda, ABD'nin petrol ayrıcalığı yalnızca Chester Projesi çerçevesinde elde edeceği alanla sınırlı olacaktı; ayrıca ABD İngiltere'ye de ters düşmüş olacaktı. Bunun yanı sıra halihazırda TBMM Hükümeti ile görüşmeleri sürdüren Amerikan Chester şirketi, petrol konusunda yerleşik bir kuruluş değildi. Halbuki Musul'un Irak'a bırakılması durumunda, Turkish Petroleum Co. tüm Mezopotamya petrollerini işletecekti. Öte yandan, İngilizlerle Mezopotamya petrollerinden pay alma pazarlığı yapan şirketler, başta Amerikan petrol devi Standard Oil Co. olmak üzere ülkenin önde gelen petrol şirketleriydi ${ }^{49}$.

Turkish Petroleum Co.'de'ki \%25 hissesi nedeniyle Mezopotamya'da petrol çıkarları bulunan Fransa ise, bu şirketteki haklarını koruyabilmek için veya bir başka deyişle Mezopotamya petrollerindeki haklarının korunması karşılığında Lozan'da Türklere Musul'u bırakmak istemeyen İngilizlere destek veriyordu ${ }^{50}$.

Sonuç olarak Amerikan temsilcilerinin Lozan'daki ilgisiz tavrı, 1923 Ocağı'nda Chester Grubu'nun mali gücü olmadığı yönünde süren propagandalar, Amerikan Dışişleri Bakanlığı'nın bu gruba olan kuşkusunun devam etmesi, Fransızların başından beri gösterdikleri şiddetli tepkiyi sürdürmeleri ve de İngilizlerin Turkish Petroleum Co.'nin kazanılmış hakları ile çakıştığına inandıkları bu projeye karşı çıkmaları; tüm bu gelişmeler, 1923 başlarında Chester Projesi aleyhine oluşan olumsuz tablonun göstergeleriydi. Ne var ki, tüm bu olumsuzluklara karşın Ankara'da ClaytonKennedy ve Arthur Chester ile TBMM Hükümeti'nin temsilcisi Nafia Vekili Feyzi Bey arasında sürdürülen görüşmeler sonucunda hazırlanan anlaşma taslağına (sözleşmelere) son şekli verildi ve 22 Ocak 1923'te Feyzi Bey tarafından İcra Vekilleri Heyeti'ne sunuldu. 30 Ocak 1923'te yapilan görüşmeden sonra ise, aynı gün, Başvekil Rauf Bey tarafından kanunlaşması

${ }^{48}$ MAE, Série Relations Commerciales 1919-1940, B. 48, Vol. 50, s. 2; MAE, Série Relations Commerciales 1919-1940, B. 48, Vol. 50, "On commence de la propagande" başlıklı, 9.11.1922 tarihli rapor, s. 84; Nouschi, s. 64 .

${ }^{49}$ Uluğbay, s. 195-196.

${ }^{50}$ MAE, Série Relations Commerciales B- produits du sol, Vol. 50, Fransız Dışişleri Bakanı'ndan Lozan'daki Fransız delegesi Barrère'e mektup, s. 110-112. Bu konuda ayrıca bkz. Uluğbay, s. 205. 
için Meclis'e gönderildi' ${ }^{51}$. Meclis komisyonlarınca yapılan bazı değişikliklerden sonra sözleşmeler 8 Nisan 1923 günü Meclis'te görüşüldü, bir gün sonra yapılan oylamayla da The Ottoman-American Development Company (OADC) ile imzalanan sözleşmeler bir kanunla onayland ${ }^{52}$. TBMM'de onaylanan sözleşmelerin içeriği şöyleydi: OADC, Türk Hükümeti'nden ne kilometre garantisi ne de başka bir para yardımı istemeden, Anadolu'da ve Musul-Kerkük-Süleymaniye bölgesinde 4.400 kilometreye yakın bir demiryolu şebekesi ve kıyılarda da üç liman yapacaktı. Karşılığında ise, inşa ettiği bu demiryolu hatlarıyla limanları ve de bu hatların iki yanında toplam 40 kilometrelik şerit içindeki bilinen ve sonradan bulunacak petrol dahil bütün madenleri 99 yıllığına işletme hakkına sahip olacaktı; ayrıca, ana sözleşmenin kesinleşmesinden sonraki altı ay içinde Türk kanun ve kurallarına uygun olarak Türklerin de ortak olacağı bir Türk Anonim Ortaklığı kuracak ve bu Anonim Ortaklık sözleşmelerdeki demiryolu ve limanların yapımı, işletmesi ve maden imtiyazlarını OADC adına kullanacaktı ${ }^{53}$. Chester Projesi olarak adlandırılan ve TBMM tarafından 9 Nisan 1923 tarihinde onaylanan demiryolu yapımı ve yeraltı kaynaklarının işletilmesiyle ilgili anlaşmanın içerdiği hatlar şunlardı:

1. Sivas- Harput- Ergani- Diyarbakır- Bitlis- (Van Gölü'nün güneyinden veya kuzeyinden) Van

2. Harput-Yumurtalık

3. (Diyarbakır-Bitlis hattının bir noktasından başlayarak) Musul-KerkükSüleymaniye

Bunlara ek sözleşmeyle eklenen yeni hatlar:

4. Samsun-Havza-Amasya-Zile-Sivas

5. Musaköy (Dördüncü hat üzerinde)-Ankara

6. Çaltı (Birinci hat üzerinde)-Erzurum-Doğu Beyazıt (İran sınırı)

7. Pikriç veya Aşkale (Altıncı hat üzerinde)- Karadeniz kıyısı (muhtemelen Trabzon)

8. Hacı Şefaatli (Beşinci hat üzerinde)-Kayseri-Ulukışla

İmtiyaz sahibi şirket tarafından inşa edilmesi öngörülen limanlar ise, biri Samsun'da olmak üzere Karadeniz kıyısında iki liman, ayrıca inşaat maliyetinin Şirket tarafından karşılanacağı Akdeniz kıyısında Yumurtalık'ta bir limandi.

\footnotetext{
${ }^{51}$ Can, s. 254.

${ }^{52}$ Meclis'te 8 Nisan günü yapılan görüşmelerin sonunda imtiyaz anlaşması oya konulmuş, oylamaya katılan 158 kişinin 141 'i olumlu oy kullandığı halde çoğunluk olmadığı için oylama ertesi güne ertelenmiştir. 9 Nisan günü 206 kişin katıldığı oylamada ise, 185 kişinin verdiği olumlu oylarla Chester İmtiyazı olarak anılan sözleşmelerin onaylanması kanunlaşmıştır. Tezel, AÜ Siyasal Bilgiler Fakültesi Dergisi, C. XXV, No. 4 (Aralık 1970), s. 294, 313.

${ }^{53}$ A.g.m.,s. 294-295.
} 
Ek anlaşmaya göre, Samsun-Sivas hattının inşasına başlanmasına öncelik verilecekti ${ }^{54}$.

Chester Projesi'nin TBMM'de onaylanması, Türkiye'de genellikle büyük coşku yaratırken ABD'de aynı ilgiyi yaratmadı. Anlaşma görüşmeleri sürerken başlayan uluslararası tepkiler ise, anlaşmanın onaylanmasından sonra daha da arttı. Zira imzalanan anlaşmada yer alan birçok demiryolu hattının yapım imtiyazı daha önce bașka gruplara verilmişti ${ }^{55}$. İngiltere Musul petrolleriyle Samsun Limanı inşaatı, Fransa ise Sivas-Samsun demiryolları imtiyazlarının bu anlaşma ile ihlal edildiğini iddia ediyor ve her ikisi de Türkiye ile ABD'yi sert bir şekilde kınıyorlards ${ }^{56}$.

TBMM tarafından anlaşmanın onaylandığı tarihlerde ise, Lozan Konferansı adli rejim, ekonomik kapitülasyonlar ve Türk-Yunan savaş tazminatı konularında anlaşmaya varılamadı̆̆ı için 4 Şubat 1923'te kesilmişti ${ }^{57}$. Durum gergindi, ancak yoğun diplomatik temaslar sonucunda 23 Nisan 1923'te konferans tekrar toplandi.

Lozan Konferansı'nın ikinci döneminde, Fransız temsilcisi General Pellé Chester imtiyaz anlaşmasının imzalanmasını şiddetle protesto ediyor, Mougin ise dolambaçlı sözler kullanmadan öfkesini ifade etmekten kaçınmıyordu. Mougin, 12 Nisan 1923 'te Fransa'nın Suriye ve Lübnan eski Yüksek Komiseri General Gouraud'ya yazılı olarak şu değerlendirmeyi yapiyordu:

“Chester Projesi'nin Meclis'te tek bir oturumda görüşülerek onaylanması ve oylanması sizi şaşırtmış olmalıdır... Ankara, Lozan'a İtilaf Devletleri'nden bağımsız, ancak Amerikalı'lara yakınlaşmış olarak gelmek istedi. Onlarla bize oranla daha kazançlt çıkacă̆ını düşünüyor. Kanun Meclis'te onaylanmadan önce İsmet Paşa ile dostça ve hükümetin politikasına burnumu sokmadan yaptı̆̆ım konuşmada, ondan şu yanıtı aldım: 'Amerika'nın dışında başka nereden para bulabiliriz?'...ve Rauf Bey şöyle diyordu: 'Amerikalı işadamlarıla Itilaf Devletleri işadamlarına göre daha az sıkıntımız olur.' Ancak sağduyu sahibi insanlar, Chester Projesi'nin gerçekleşemeyeceğini biliyorlar..." 58

Pellé'nin yanı sıra Fransız Hükümeti, Chester imtiyazının 1914'te yüklü bir borç karşılığında Fransızlara verilen imtiyazları kapsadığı gerekçesiyle 11 Nisan 1923 'te Ankara Hükümeti'ne sert bir protesto gönderiyordu.

\footnotetext{
${ }^{54}$ Can, s. 268; anlaşma koşulları hakkında daha ayrıntılı bilgi için bkz. A.g.m., s. 295-303.

${ }^{55}$ A.g.e., s. 272.

${ }^{56}$ İlkin, Türkiye Işs Bankası Uluslararası Atatürk Sempozyumu: Bildiriler ve Tartışmalar, s. 777.

${ }^{57}$ Salâhi R. Sonyel, Türk Kurtuluş Savaşı ve Dış Politika II, Ankara, TTK, 1986, s. 330.

${ }^{58}$ Paul Dumont, "A l'aube du rapprochement franco-turc: le Colonel Mougin, premier représentant de la France auprès du gouvernement d'Ankara (1922-1925)," La Turquie et la France à l'époque d'Atatürk, Paris, Association pour le développement des études turques, 1981 , s. 85 n 19 .
} 
Fransızların tepkisinin esas nedeni, bu anlaşmayla Chester Grubu'na verilen Sivas-Samsun demiryolu hattı imtiyazının 1914 yılında yapılan bir anlaşmayla Fransızlara verilmiş olmasıydı. Fransızlar, Chester Grubu ile yapılan imtiyaz anlaşmasını ayrıca Ankara Hükümeti tarafından kendilerine tanınan haklara da aykırı olduğu gerekçesiyle protesto ediyorlard ${ }^{59}$. Ancak Ankara, Fransızların bu itirazlarına önem vermiyordu. Zira Türk tezine göre, Fransızlara verilmiş ayrıcalıkların hiçbir hükmü yoktu; bunlar TBMM yönetimince verilmediği gibi Osmanlı parlamentosunda da onaylanmamış, ayrıca Fransız bankerleri tüm koşullara uymamışlardı ${ }^{60}$.

Birinci Dünya Savaşı'ndan önce Osmanlı yönetimi tarafından İtilaf Devletleri'ne verilen onaylanmamış imtiyazlar sorunu, esasında barış antlaşmasının imzalanmasında en büyük engellerdendi. Mougin'in tahmin ettiği üzere ve Gouraud'ya yaptığı değerlendirmede de vurguladığı gibi, Türk delegasyonu Lozan'ın ikinci dönem görüşmelerinde bu konuda Amerikalılar'dan yardım alacaktı; şöyle ki, eski imtiyazların geçersiz olduğunu ve yalnız TBMM tarafından onaylanmış yeni imtiyazların geçerli olduğunu savunan Türk delegasyonu, bu mücadelesinde Amerikalıları yanında buluyordu. İngiliz ve Fransız temsilcileri, Türklerden İngiliz Vickers Armstrong ve Fransız Régie firmalarının imtiyazlarını onaylamalarını, yerlerine yenilerini koymalarını ya da onlara 10 yıl süre ile tercih hakkı tanıyarak tazminat ödemelerini, ayrıca Turkish Petroleum Co.'nin haklarını tanımalarını talep ediyorlardı. Fakat bu imtiyazlar hem Chester imtiyazına hem de Amerikan ticari çıkarlarına aykırıydı. Ve Lozan'daki Amerikan temsilcisi Grew, İtilaf Devletleri'ne imtiyaz tanıyan maddelerin antlaşmadan çıkarılmasını talep ediyor ve ABD'nin Türkiye ile ayrı bir ticaret anlaşması imzalayacağını söylüyordu. İsmet Paşa ise,

${ }^{59}$ Can, s. 291. 1914 tarihinde Fransızlarla yapılan anlaşma konusunda farklı bilgiler bulunmaktadır. Şöyle ki, Bilmez Bülent Can'ın Amerikan kaynaklarına dayanarak verdiği bilgilere göre, Fransızlar, 1914 yılında Osmanlı Hükümeti ile yaptıkları anlaşmayla SamsunSivas demiryolu hattının ve Samsun Limanı'nın imtiyazı ve bazı konularda öncelik hakkı verilmesi karşılığında 800 milyon frank borç vermeyi kabul etmişlerdi. Bu anlaşma, 8 Nisan 1914 tarihli bir padişah iradesi ile onaylanmıştı. 14 Temmuz 1914'te ise parlamentoda yapılan görüşmelerden sonra borç anlaşması onaylanmıştı. Bu anlaşma doğrultusunda 500 milyon frank ödeme yapan Fransızlar, Sivas-Samsun demiryolunun yapımına başlamışlar, ancak Birinci Dünya Savaşı'nın patlak vermesi nedeniyle savaşın başında çalışmalarını durdurmuşlardı. A.g.e., s. 292. Ali Naci Karacan ise, Fransızlar için kazanılmış bir hak bulunmadığını, çünkü sözleşmelerin tam olmadığını, hatta Samsun-Sivas hattına dair sözleşmenin yalnız müsveddesinin yapıldığını ve Fransızların baskısıyla parafe edilen müsvedde üzerine asıl sözleşmeyi yapmak için hükümetin padişahtan bir irade ile izin aldığını, ancak bu izne karşın hükümetin sözleşmeyi tamamlayamadığını, öyle ki Meclis'in bile bunun yapılmasına karşı bir tavır aldığını yazmıştır. Karacan, böylesine ihtilaflı bir sözleşmeyi kendisine kabul ettirmeye çalışan Fransızları İsmet Paşa'nın Birinci Lozan Konferansı'nın son gecesi gazetecilere "Bana görmediğim, bilmediğim birtakım mukaveleleri imza ediniz diyorlar!" diye şikâyet ettiğini ve bu konunun konferansın kesilmesinin nedenlerinden biri olduğunu belirtmiştir. Karacan, s. 330 .

${ }^{60}$ Sonyel, C. II, s. 341. 
Türkiye'de "nüfuz bölgeleri"nin oluşmasına yardımcı olacağı gerekçesiyle ne Turkish Petroleum Co.'ye ne de Vickers Armstrong ve Régie şirketlerine tercih hakkı vermeye razı oluyordu. Sonuçta, İtilaf Devletleri imtiyazlar konusunda ödün verdiler. İsmet Paşa ise sonuna kadar direndi ve Chester imtiyazıyla ters düşen Turkish Petroleum Co.'yi tanımayı reddetti ${ }^{61}$. Ve de Grew'un katılmadığı son oturumlar sonunda, Türk ve Amerikan delegasyonlarının isteği doğrultusunda savaş öncesi tüm imtiyaz anlaşmalarının geçersiz olduğu kabul edildi ${ }^{62}$.

İşte Lozan'da tüm bu görüşmeler sürerken Fransız şirketlerinin temsilcileri, Fransız Başbakanı Poincaré'nin ve İstanbul'daki Yüksek Komiser Pellé'nin teşvikiyle 1923 Mayısı'nda Ankara'ya gidiyorlar ve burada Mougin üzerinde çok iyi bir izlenim bırakacak bir atmosferde temaslarda bulunuyorlardı. 1 Temmuz'a gelindiğinde ise Ankara'da pek çok sorun çözümlenmişti, fakat Türk Hükümeti 16 Mart 1920 öncesi yapılan tüm anlaşmaları tanımayı reddediyordu. ${ }^{63}$. Sonuç olarak Fransızların Chester Projesi'ne itiraz etmelerine neden olan Samsun-Sivas demiryolu hatt1 imtiyazı sorunu Lozan'da şöyle çözülecekti: Lozan Barış Antlaşması ile birlikte 24 Temmuz 1923'te imzalanmış olan "Osmanlı İmparatorluğu Memalikinde İta Edilmiş Bazı İmtiyazlara Dair Protokol ve Beyanname" nin 2. maddesine göre, şayet Antlaşmanın yürürlüğe girmesinden itibaren altı aylık bir süre zarfında Régie Générale des Chemins de Fer şirketi kendisine 1914 'te verilmiş olan Samsun-Sivas demiryolunun inşası ve işletilmesi hakkındaki imtiyaza sahip kılınmazsa, Türk Hükümeti ya yeni bir imtiyaz verecek ya da eksperler tarafından belirlenecek bir tazminat ödeyecektir. Ne var ki, 1919'dan beri Régie Générale des Chemins de Fer'in sözleşmelerin yeniden gözden geçirilmesinden sonra çalışmalara başlamaya hazır olduğunu açıklamasına karşın, TBMM Hükümeti imtiyazı Chester'in OADC'sine vermeyi tercih etmişti ${ }^{64}$.

${ }^{61}$ A.g.e., s. 353-355. ABD ile Türkiye arasında 6 Ağustos 1923 'te "Dostluk ve Ticaret Antlaşması" imzalanmıştır. Utkan Kocatürk, Atatürk ve Türkiye Cumhuriyeti Tarihi Kronolojisi1918-1938,2.B.,Ankara, TTK, 1988, s. 391.Lozan'da tartışma konusu yapılan Fransız Régie firması, Régie Générale des Chemins de Fer'dir.

${ }^{62}$ Can, s. 311.

${ }^{63}$ Jacques Thobie, "Une dynamique de transition: les relations économiques francoturques dans les années 20", La Turquie et la France à l'époque d'Atatürk, Paris, Association pour le développement des études turques, 1981, s. 148-149; Bu konuda ayrıca bkz. Sina Akşin, "Kurtuluş Savaşında ve Lozan'da İngiltere ve Fransa ile İlişsiler”, Atatürk Döneminin Ekonomik ve Toplumsal Tarihiyle Ilgili Sorunlar Sempozyumu, İstanbul, IYİTMMD Yay, 1977, s. 130; Karacan, s. 377;

${ }^{64}$ Thobie, La Turquie et la France à l'époque d'Atatürk, s.153-154; protokol metni için bkz. Dıșişleri Bakanlığı Araştırma ve Siyaset Planlama Genel Müdürlüğü, Türkiye Dış Politikasinda 50 Yil: Lozan (1922-1923), Ankara, 1973, s. 291-295. Lozan'dan sonra, mali sıkıntı içinde bulunan OADC adına Kennedy, Régie şirketinin Başkanı Kont Vitali'ye Samsun-Sivas demiryolu hattını devretmeyi önermiş, fakat Kont Vitali Osmanlı Bankası'nın da görüşünü aldıktan sonra bu öneriyi reddetmişti. Daha sonra, Amerikan şirketinden ümidi 
Fransa'nın Ankara'daki temsilcisi Albay Mougin'in Chester imtiyaz anlaşmasının imzalanmasından kısa bir süre sonra belirttiği gibi Chester Projesi gerçekleşemeyecekti. Her ne kadar proje resmen TBMM'de kabul edilse bile, ABD Hükümeti projeyi resmen desteklemeye istekli değildi. Bir yandan Chester Grubu içindeki sürtüşmelerin devam etmesi, diğer yandan Mezopotamya, dolayısıyla Musul petrollerinden pay almak isteyen ve Turkish Petroleum Co. ile işbirliği görüşmelerini sürdüren Amerikan petrol grubunun ABD Hükümeti üzerine yaptığı baskı, onu Chester Projesi'ne karşı böyle bir tavır almaya iten nedenlerdendi. Lozan'da ikinci dönem görüşmeler sırasında, Musul sorunu konusunda Chester Grubu doğal olarak Ankara Hükümeti'nden yana tavır alırken Mezopotamya petrollerinden pay almak isteyen büyük Amerikan petrol şirketlerinden oluşan grup ise karş1 savı destekliyor ve bu doğrultuda kulis çalışmaları yapıyordu. Sonuçta uzun tartışmalara karşın Lozan'da Musul sorunu çözülemiyor ve sorunun çözümü, Lozan Barış Antlaşması'nın 3. maddesiyle, dokuz ay içinde bir sonuca ulaştırılmak koşuluyla Türkiye ile İngiltere arasındaki ikili görüşmelere birakiliyordu ${ }^{65}$.

\section{Sonuç}

Chester Grubu ile imtiyaz anlaşması imzalanmasına karşın Chester Projesi uygulanamamıştır. Burada rol oynayan faktörlerden birisi, anlaşmanın imzalanmasından hemen sonra şirket içinde çıkan anlaşmazlıklar ve bunun sonucunda Chester'in başını çektiği Amerikalı ortaklarla Kennedy'nin başını çektiği Kanadalı ortakların yollarının ayrılması idi. ABD'li ortakların şirketten ayrılması, yatırımın finansmanı sorununu beraberinde getirdi. Her ne kadar Kennedy, aralarında Standard Oil'in de bulunduğu $\mathrm{ABD}$ menşeli mali kuruluşlara başvuruda bulunup, ayrıca İsviçre, Fransa ve İngiltere'de yeni olanaklar aradıysa da girişimlerinden hiçbir sonuç alamadı. Kaldı ki, tüm bu arayışlar projenin öngörülen sürede başlamasını engelliyordu. Üstelik bu arada Lozan barış görüşmeleri sonuçlanmış ve Musul sorunu çözülememişti. Güçlü Amerikan konsorsiyumu Standard Oil ise, Turkish Petroleum Co.'ye katılmak için başlattığı görüşmelerde büyük mesafe katetmişti ${ }^{66}$. Bunun da ötesinde, ABD Dışişleri Bakanlığı'na finans kuruluşlarının Chester Projesi'ne mali destek

kesen Ankara Hükümeti, Régie şirketine Samsun-Sivas demiryolu hattının yapım ve işletme imtiyazını önermişti. Ancak Fransız şirketine göre, bu öneri 1914'te imzalanan sözleşmelere aykırı olduğu gibi mevcut koşullarda gerçekleşmesi de mümkün değildi. Bunun da ötesinde Lozan'da imzalanan protokolde Fransız şirketinin imtiyaza sahip olması için öngörülen süre geçirilmişti. Bundan sonra ise, Fransız şirketiyle Türk Hükümeti arasında tatsız tazminat görüşmeleri başlayacaktı. Sonunda Türk Hükümeti Samsun-Sivas hattını millileştirecek, Karadeniz demiryolu şebekesinin yapımını ise Bir İsveç grubu ile bir Alman Grubu'na teslim edecekti. Thobie, La Turquie et la France à l'époque d'Atatürk, s. 154.

${ }^{65}$ Can, s. 306-309.

${ }^{66}$ İlkin, Türkiye İs Bankası Uluslararası Atatürk Sempozyumu: Bildiriler ve Tartışmalar, s.778-779. 
vermeyecekleri yönünde bilgiler geliyordu. Bunun üzerine ABD Dışişleri, Amerikan petrol şirketleri adına Turkish Petroleum Co. ile görüşmeleri yürüten Standard Oil'in Başkanı Teagle'a 8 Kasım 1923 günü girişimleri için gereken diplomatik desteği vermeye hazır olduğunu bildirdi ${ }^{67}$. Dolayısıyla böyle bir ortamda Kennedy'nin proje için mali destek arayışlarının sonuç vermesi beklenemezdi. Bununla birlikte Kennedy, TBMM Hükümeti'nin anlaşmayı feshetmesini önlemek için Sivas-Samsun hattının yapımına başlamak gibi bazı çarelere başvurmayı ihmal etmeyecek, ne var ki bunlar da bir işe yaramayacaktı. Diğer yandan ABD Dışişleri Bakanı, Ankara'nın Chester Grubu'nun işe başlamamasından duyduğu rahatsızlığ kendilerine ileten İstanbul'daki Amerikan Yüksek Komiseri'ne verdiği 12 Kasım 1923 tarihli yanıtta, Sivas-Samsun demiryolu için hiçbir Amerikan şirketi veya grubunun kredi vermek konusunda istekli olmadığını bildirecekti. Ankara ise bu haberi aldıktan sonra bir süre daha bekleyecek ve sonuçta TBMM Hükümeti 18 Aralık 1923'te anlaşmayı feshettiğini açıklayacaktı ${ }^{68}$.

Chester Projesi hakkında genel bir değerlendirme yapılacak olursa, bu konuda şimdiye kadar yapılan bilimsel çalışmalarda da sıkça vurgulanan iki ilginç olgu karşımıza çıkmaktadır. Bunlardan birisi, yeni Türk Devleti'nin, topraklarını emperyalist güçlerin işgalinden kurtardıktan sonra ticaret anlaşmalarıyla, borç sözleşmeleriyle, Düyun-u Umumiye teşkilatıyla Osmanlı İmparatorluğu'n yarı sömürge haline getiren devletlerle bu kez diplomasi masasında yüzyıllık sorunlarını çözmeye çalıştığı bir dönemde yabancı bir çıkar grubuyla bir imtiyaz anlaşması yapmasıdır. Öbürü ise Chester Grubu ile yapılan imtiyaz anlaşmasının TBMM'de onaylanmasına karşın Chester Projesi'nin eyleme dökülememesidir. TBMM Hükümeti, bir yandan Chester imtiyazı kanalıyla Lozan'da İngiltere ve Fransa gibi Batılı devletler karşısında ABD desteğini sağlamak, diğer yandan Lozan görüşmelerinin kesintiye uğradığı bir dönemde Amerikalılarla bir imtiyaz anlaşması imzalayarak yabancı sermayeye karşı olmadı̆̆ını göstermek,

${ }^{67}$ Uluğbay. s. 245. Musul ve çevresinin Lozan Antlaşması ile Türkiye'ye verilmemiş olması nedeniyle bölgenin geleceğinin belirlenmesinin uzun zaman gerektireceği görüşü, finans kuruluşlarının Chester Projesi'ne sıcak bakmamalarında rol oynayan temel faktördü. Mali kuruluşlar, Amerikan petrol şirketlerinin Musul petrollerine ortak olmasına yeşil ${ }_{1 s ̧ ı k}$ yakan İngiltere'nin Lozan sonrası ikili görüşmelerde ABD siyasi engelini aşmış olarak Türkiye'ye daha güçlü direneceğine ve konuyu Milletler Cemiyeti'ne götürerek burada isteklerini kolayca kabul ettireceğine inanıyorlardı; dolayısıyla Musul'suz bir Chester Projesi'nin Türkiye sınırları içinde kalan bölümüne mali destek verme eğilimi taşımıyorlardı. A.g.e., s. 244-245. Hikmet Uluğbay bu bilgileri verirken Niyazi Acun da, bazı güçlü petrol tröstlerinin Chester Grubu'nun "Wall Street"ten mali yardım almasını engellediklerini, ABD Dışişleri'nin de bu tröstlerin etkisi altında kalarak onlara hizmet ettiğini ileri sürmektedir. Niyazi Acun, Dünya Petrol Tarihi ve Türk Petrolü,IStanbul, Șaka Matbaası, 1949, s.150.

${ }^{68}$ Uluğbay, s.245. Kennedy, Ankara'yı oyalamak için Samsun-Sivas hattının yapımına başlamıştı. Ne var ki bunun eski güzergâh üzerinde bir vakit geçirme olduğu anlaşıldı. İlkin, Türkiye İs Bankası Uluslararası Atatürk Sempozyumu: Bildiriler ve Tartışmalar, s. 779. 
dolayısıyla, görüşmelerin kesilmesinde önemli rol oynayan kapitülasyonların kaldırılmasını sağlamak istiyordu. Öyle ki Lozan görüşmelerinin kesintiye uğradığı dönemde, 17 Şubat 1923'te İzmir'de Türkiye İktisat Kongresi toplanmış ve Gazi Mustafa Kemal Paşa Kongre'yi açış konuşmasında, yabancı sermayeye karşı olmadıklarını, ülkenin çok geniş olduğunu ve sermayeye ihtiyaç duyulduğunu, dolayısıyla Türk kanunlarına saygılı olmak koşuluyla yabancı sermayeye açık olunduğunu, ancak, devletin geçmişte olduğu gibi yabancı sermayenin jandarmalığını yapmayacağını ve Türkiye'yi esir ülkesi yaptırmayacaklarını açıkça söylemişti ${ }^{69}$. Ulu Önder'in bu sözlerinden yola çıkıldı̆̆ında ise, TBMM'nin Chester Projesi'ni onaylamasının bir başka temel nedeni olarak, karşımıza Osmanlı'dan ekonomik ve mali bir enkaz devralarak çağdaş, tam bağımsız ve kalkınmış bir ülke olmak isteyen, ne var ki kalkınmasını kendi olanaklarıyla gerçekleştiremeyecek bir durumda bulunan bir devletin içinde bulunduğu güç koşullar çıkmaktadır. Ve de TBMM Hükümeti, Meclis'te, demiryollarını kendi olanaklarıyla yapma gücüne sahip olmadığını, bu nedenle yabancı sermayeye başvurmak zorunda olduğunu açıkça ilan etmişti. Bunun yanı sıra hükümet çevrelerine göre, Amerikalı sermayedarlara tanınan maden ayrıcalığı yabancı sermayenin Türkiye'de yapacağı alt yapı yatırımlarının ödenmesi gereken bir bedeliydi ${ }^{70}$.

Araştırmamıza konu olan ve 19. yüzyılın ikinci yarısından itibaren yaptığı sermaye yatırımlarıyla ve verdiği borçlarla Osmanlı İmparatorluğu'nda ekonomik açıdan üstün bir konuma sahip olan, Birinci Dünya Savaşı öncesi ise \%59 oranında bir payla toplam yabancı sermaye yatırımları içinde birinci sırada yer alan ${ }^{71}$ ve TBMM Hükümeti ile imzaladığ 20 Ekim 1921 tarihli Ankara Anlaşması ile yaptığı yatırımların ve verdiği borçların geleceğini bir süre için de olsa korumaya çalışan Fransa, ABD'nin 1922 başlarından itibaren başta Türkiye olmak üzere Yakın-Doğu'da ekonomik nüfuzunu artırma çabalarını dikkatle izlemeyi ihmal etmiyordu. Fransızlar, Amerikalı sermayedarların özellikle demiryolu ve liman yapım imtiyazı almak için Ankara Hükümeti ile görüşmelerinden, en çok da daha başından beri kendi nüfuz alanlarını tehdit eden Chester demiryolu projesinden rahatsız oluyorlardı. Ve de son derece iyi çalışan istihbarat ağları vasıtasıyla, özellikle Ankara'daki temsilcileri Albay Mougin kanalıyla Chester Projesi ile ilgili gelişmeleri yakından takip eden Fransız yöneticileri, aldıkları raporlar ışığında, Türk yetkililerinin ülkenin ekonomik açıdan kalkınabilmesi için yeterli sermayenin bulunmadığının bilincinde olduklarını

\footnotetext{
${ }^{6}$ Gündüz Ökçün, Türkiye iktisat Kongresi 1923-Izmir, 3.B., Ankara, AÜ Siyasal Bilgiler Fakültesi Yay., 1981, s. 252-253.

${ }^{70}$ İcra Vekilleri Heyeti Başkanı Rauf Bey'in ve Nafia Vekil Feyzi Bey'in konuşmaları için bkz. Tezel, AÜ Siyasal Bilgiler Fakültesi Dergisi, C. XXV, No. 4 (Aralık 1970), s. 308310.

${ }^{71}$ MAE, Série E Levant Turquie, Vol. 169, M. Boissière'den Fransız Dışişleri Bakanı'na "Importance des capitaux français, anglais et allemands engagés en Turquie" başlıklı, 30.5.1919 tarihli memorandum, s. 92-94.
} 
ve ihtiyaç duyulan sermayeye yalnızca ABD'nin sahip olduğuna inandıklarını biliyorlardı. Bununla birlikte Chester Grubu ile imtiyaz anlaşmasının imzalanmasına ve TBMM'de onaylanmasına şiddetle tepki gösteren Fransız resmi çevreleri, Türkiye'den gelen ve "Türk Hükümeti'nin Amerikalılara yanaşmayı çıkarları açısından daha yararlı bulduğu, şiddetle paraya ihtiyaç duyan Ankara'nın Chester Projesi'ni kabul ettiği ve Lozan görüşmelerinin kesildiği bir dönemde TBMM'de anlaşmayı onaylayarak Lozan'da (ikinci dönem oturumlarda) ABD desteğine sahip olmak istediği”" yönünde bilgiler içeren raporlarla Chester İmtiyazı'nın Ankara tarafından kabul edilmesinin nedenlerini anlamaya çalışıyorlardı.

Başlangıçta bir demiryolu projesi iken Birinci Dünya Savaşı'ndan sonra petrol imtiyazı projesine dönüşen Chester Projesi'nin başarı şansı konusunda ise Fransızlara çelişkili bilgiler geliyordu. Buna karşın, örneğin Mougin, başlangıçta projenin başarı şansının bulunduğuna inanırken imtiyaz anlaşmasının TBMM'de onaylandığ 1 günlerde projenin hayata geçirilemeyeceğini Paris'e bildirmiş ve bu görüşünde de haklı çıkmıştı. Şöyle ki, Mezopotamya petrollerinden, dolayısıyla Musul petrollerinden pay almak isteyen Standard Oil Co.'nin başını çektiği Amerikan petrol grubu, Lozan'da, bir yandan İngiliz sermayesinin egemen olduğu, ancak Fransızların da \%25 hisseye sahip olduğu Turkish Petroleum Co. ile ortaklık görüşmelerini sürdürmeye devam ederken, diğer yandan Musul'un Türkiye'ye bırakılmaması yönünde kulis yapıyor, ayrıca ABD Hükümeti üzerinde baskı uyguluyordu. Turkish Petroleum Co.'deki hisselerini koruma kaygısı içindeki Fransızlar ise, Mezopotamya petrollerindeki haklarını garanti altına alabilmek için Lozan'da Musul'u Türklere bırakmak istemeyen İngilizlere destek vermekten kaçınmıyorlardı. Sonuç olarak, gerek büyük devletlerin petrol çıkarlarının gerekse Chester Grubu ile Standard Oil'in başını çektiği Amerikan petrol şirketleri arasındaki rekabetin ve de Lozan sonrası Amerikan Dışişleri'nin açıkça dev Amerikan şirketlerinden yana tavir almasının hem Musul sorununun hem de Chester Projesi'nin geleceğinde belirleyici rol oynadığını söylemek kanımızca gerçek dışı bir yaklaşım değildir. 
EK I- Fransa'nın Ankara'daki temsilcisi Albay Mougin'in Chester Projesi ile ilgili Ankara'daki gelişmeleri Fransız Dışişleri Bakanlığı'na bildiren telgrafı. Château de Vincennes, 7 N 3257, D. 1, Mougin'in 26.10.1922 tarihli telgrafını Fransız Dışişleri Bakanlığı'na ileten İstanbul'daki Fransız Yüksek Komiseri Pellé'nin 30.10.1922 tarihli telgrafı. 

MINISTE⿱丶万仒⿸尸 fo COMMFRCE ET TUE LINIUUSTRIK

DIRECTION

DES ESSENCES ET PÉTAOLES

\author{
$3.48 .2 \not 16$ \\ 81 \\ OIL \& GAS JOURNAL - 9 NOVOMbrO I922.-
}

\section{SERVICE D'INFORMATIONS}

LA CONCESSION DE L'AMIRAL CHESTER EST CONFIRMEE

washington - 4 Hovembre.- L'Industrio pétrolière des Etats Unis aporendra avec beaucoup d'intérêt que les grands gisements de pétrole de "résoo potamie sont mointonant on sécurits dans los mins d'intérôts américaing Les rensoinnenents roçus par cable donnont à gotte dóclaration une auorité complète. Ie Gouverionont Turo a renouvelś at contimé la concossion obt nus par I'Aniral Colby $\cdots$. Chester, ar batant ortto oonoge-

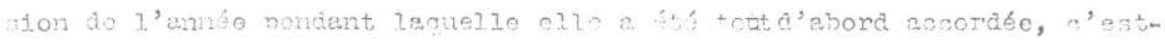

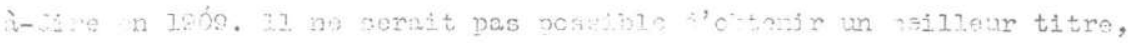
car toütas nńcautions ont ́tó prisng nar lo Gouvernement Ture on vue de placer l'Aniral Chester dans une position qui ne pornetto pas do discuter ses droits.

in fait, ses droits étaiont nntiòromont próservés avant mêno que la confirmation do le concession ait its faite par le Gouvernement urc. La promitre concoseion contenait :: a Isnse on vortu de laguelio, on cas d'uno guerre rendant impossihls I'áxícution des clauses de la concession, les drolts a:cordés par ln concession rosteraient on suspens. Les fuorres turades sont intorronues jus id' va prondre activenent des mesures poup exćcutor los travaux préliminairos d'exploration et vórifier la structura póologiaue.

La concession Chester próvoit le songtruction de 1.200 millos

sviron do voies Forréso, qui conprent in continution du oliemin de fer de Baghdad vors l'ost jusmu'à la erontiòre do la Perso. En outro, los

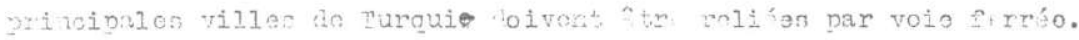

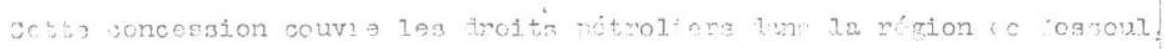
de sinós per tant l'int úcôts anvuis 20 ans

EK II- Chester Projesi'nin tarihsel gelişimi ile ilgili yazı. MAE, Série Relations Commerciales, B. 48, Vol. 50, 9.11.1922 tarihli Oil \& Gaz Journal'de yer alan "La Concession de l'Amiral Chester est confirmée" başlıklı yazı. 
Antérieurement à la guerre, la plug grende partio dos études, nécessitéos par cette concession, ont été faites, et I'emplacement général des gisements de pétrole déterminé.

Les conditions auxouelies la concession de l'Amiral chester a été confirmée, sont bien connues de tous nos services gouvernementaux intéressés. On se rappelle que les premières démarches ont été faites sous la présidence de Roosevelt. C'est en 1899 que I'Amiral Chester alla en Turquie, avec le croiseur Kentucky, dens le but a'obtenir le ròglement d'une indomnité résultant dos massacres de 1896 pondant losquels la propriété do missionnaires ambricains fut détruite. L'Amiral Chester condujsit, Ios négociations avoc tant de tact nu'au liou do coj.ro du Sultan, Abdul ilamid, un ennemi dos Etats Unis, il on fit un grend ami. L'effet protuit sur le Gouvernoment murc fut tel qu'il on rérulta. la commande d'un croiseur turc aux Itats Unis.

En 1908 il y gut une erande augmentation dans les relations commerciales des Itats unis et de la rurquio, et I'Amiral chester fut envoyé par l:a Chambre de Commerce de Ner York, on Turquie dans le. but d'augmenter encore ces relations commerciales.

d'est en 1908 que le sultan offrit pour la premì̀re fois à I'Amlral Chester une vaste concession pour la construction de nombreux travaux publics on Turauie.

Les concessions actuelles de chemin de fer comportent l'attribution de terrains de chaque coté de la voie ferrée. Des travaux conoidérables ont étés jaits par les intérêts choster dans le but de préparer I'execution de leurs engagements. Trois conpagnies ont été fondéos. I'une: ost l'Ottoman Americen Development Co, do Constentinonle, la soconde ast l'ottoman American Iroustrial co et 10 trojeième l'ottoman Arerican Ictroloum Co. L'Anerican Dovolopmont co wt. la "inolding compir. I'Indastrial co est celle qui construira le voio forrée ot gr: pré-

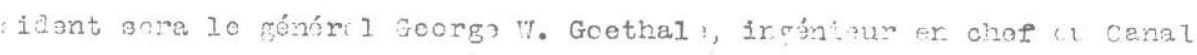

\section{EK II a}


de Panama, qui réside aotuellement à New York.

Les termes de cetté concession ont été conçus de façon très I1béralo pour assurer la coopération des intérêts considérés comme log plus ut1les. En co qui concerno les intérêts qui dolvent coopérer, on sait très bien que l'administration et le Congrès sont au courant de I'affaire, à tel point que ce qu'ils accompliront présentera un intérêt national. Pour le moment ce n'est qu'une entreprise purement privéo qui jouira de la protection accordée aux intérêts de tout citoyen américain. La construction de ce chemin de fer et l'exploitation dos gisements de pétrole de Iésopotamie auront pour les Jtats Unis une importance plus srande que celle représontée par les bénéfices que retireront les concessionnaires des termes de lour concession. Flle entrainera I'achat aux Btats Unis a'une grande quantité de matériol de forage et de raffinage, de même que de matériel de voies ferrées et de matériel roulant.

Le Commander Arthur I Chester est actuellement en Turauie où il s'occupe de cos concessions. Il est le fils de I'Amiral Chester, cui est rontré aux Etats Unis. Il se trouve, dans les milieux officiels, politigues ot financiers, de nombrouses personnes qui sont au courant des évènoments de cos quinze dernières années, qui ont aidé directement au règlement de cette grande entreprise, pour laquelle ils ont la plus entière confiance. 


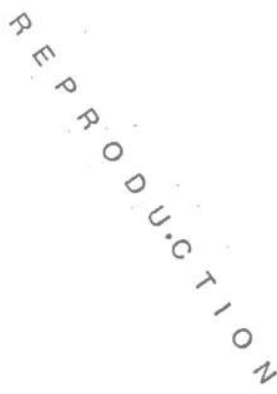

FIUDS SUR LEE PROJETS DE GRETII DE PER

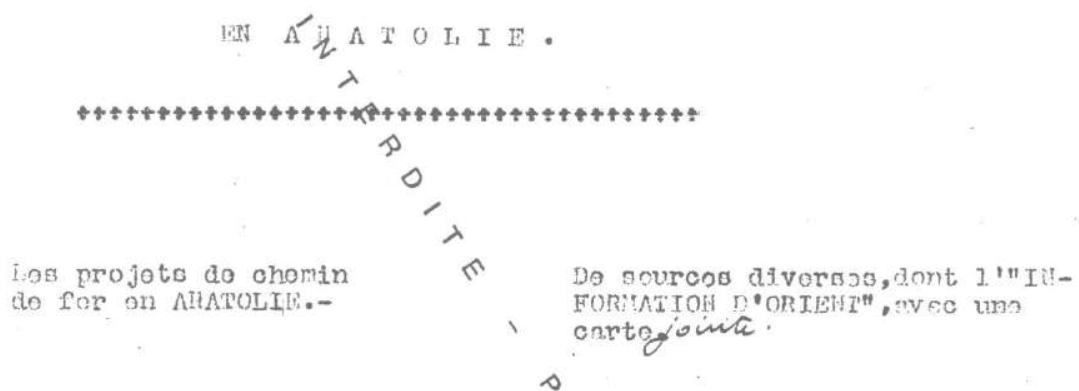

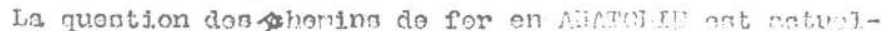

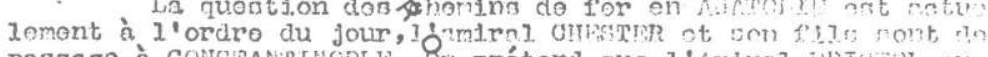

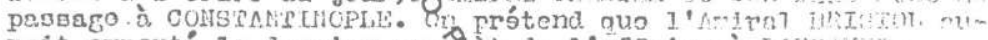

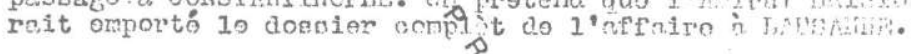

$$
\text { I.- I, Drojot OSK [N.1? }
$$

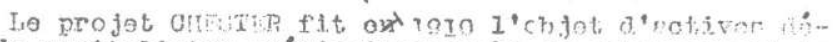

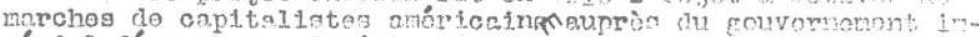
pórial, dómarchos qui n'ebcutjent pes. Ine garentio do 70.0m

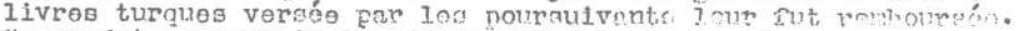
Co projet comportait in construction do tred" ifrnog :

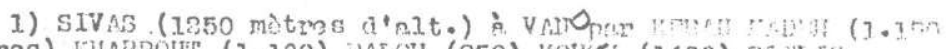

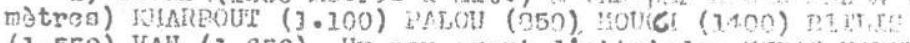

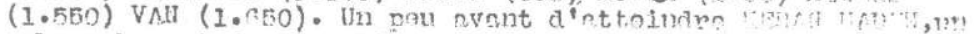

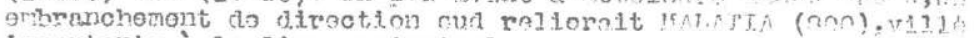
importante, à, lo limm pringipn?o.

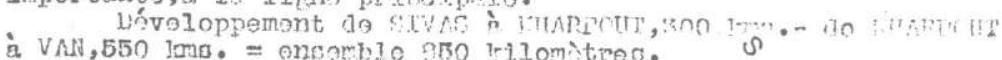

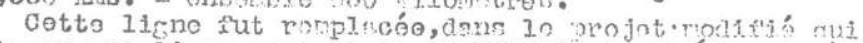

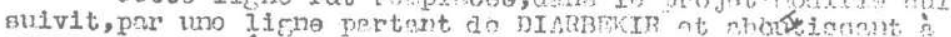

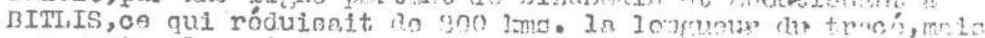

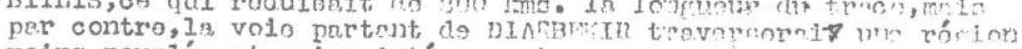

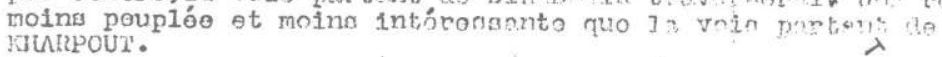

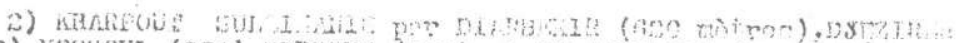

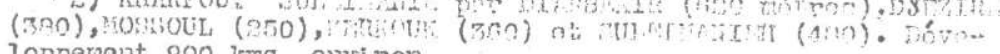
lopperasut $900 \mathrm{kms}$. onviron.

EK III- Chester Projesi'nde 1910'dan itibaren meydana gelen değişiklikleri irdeleyen rapor. Château de Vincennes, 7 N 3257, D. 1, "Etude sur les projets de chemins de fer en Anatolie" başlıklı rapor. 


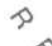

s

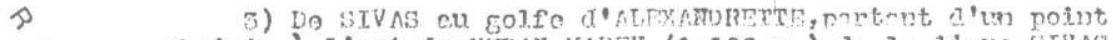

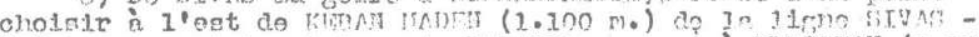

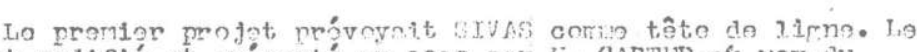

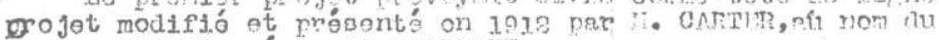

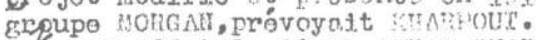

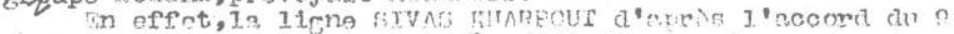

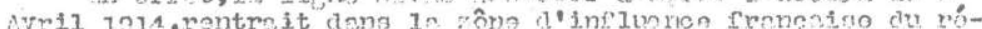

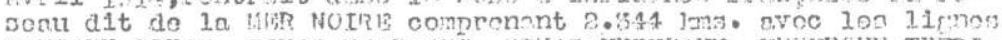

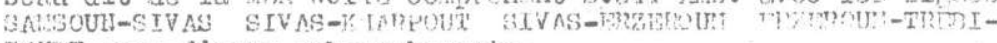
TUitD a a divor mbranchomentis.

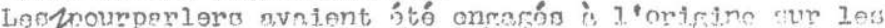

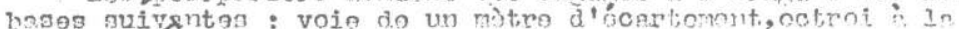

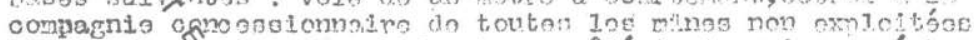

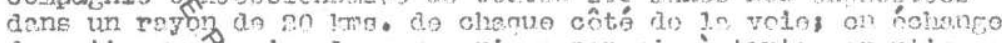

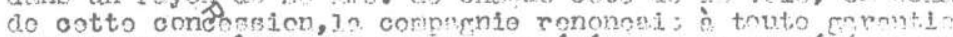

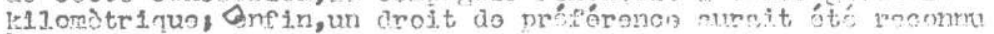

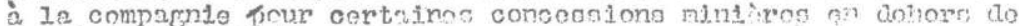
1. zôno do 40 kmd.

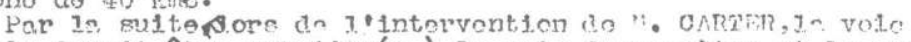
normalo तevelt être cuhstityéo a 73 vole do un mitro, nt. 7 nerticipeti on ju gouverpoment, ¿. le.constitution du copitin fut onvigagéo.

II n'o pna śté popjible do Eavojr où en sont los nompre-

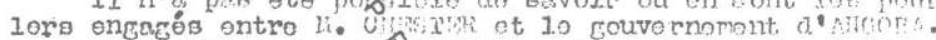

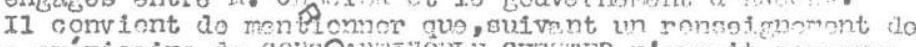

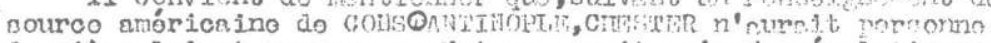
dorrì̀ro luj et que onn preqlot no sorait "u'une srículotion : Is chose est pleusihle si jon considire d'um part que dis jà

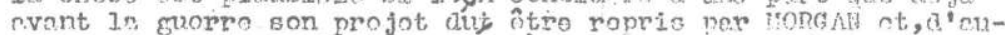

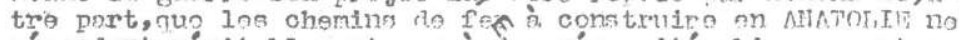
pópondont vórttablement pas à dog nócosaitós bion upesontos ni. ¿ des espóranoes bion tontintor.

Il ouffit do se rnppoler gue 1 MNMTCI.IS compto mintensut 1) milizong d'liabitanto environ et de voir nuol iorroin ol quelles cltitudos omprunteront les limer onviengsos.

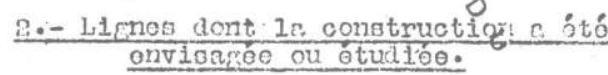

\section{SLIVA, contro du}

\section{roseau}

Le contre de gravitá de I'AIn'torif act romrósenté par to villo do SIVAi;. Si, sur un carto is ce prya on tmoa mo limpn

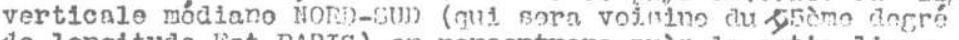
do longitude Est PARIS) on rencontrorr, pi*in do ootto lime,

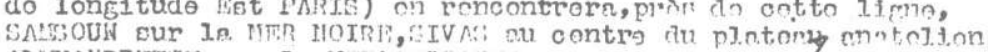

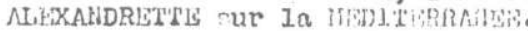

\section{Lout grandos artires prinot-

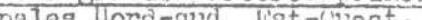

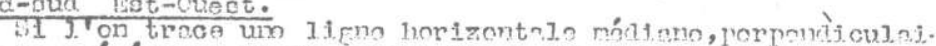

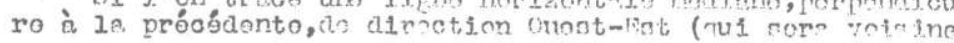




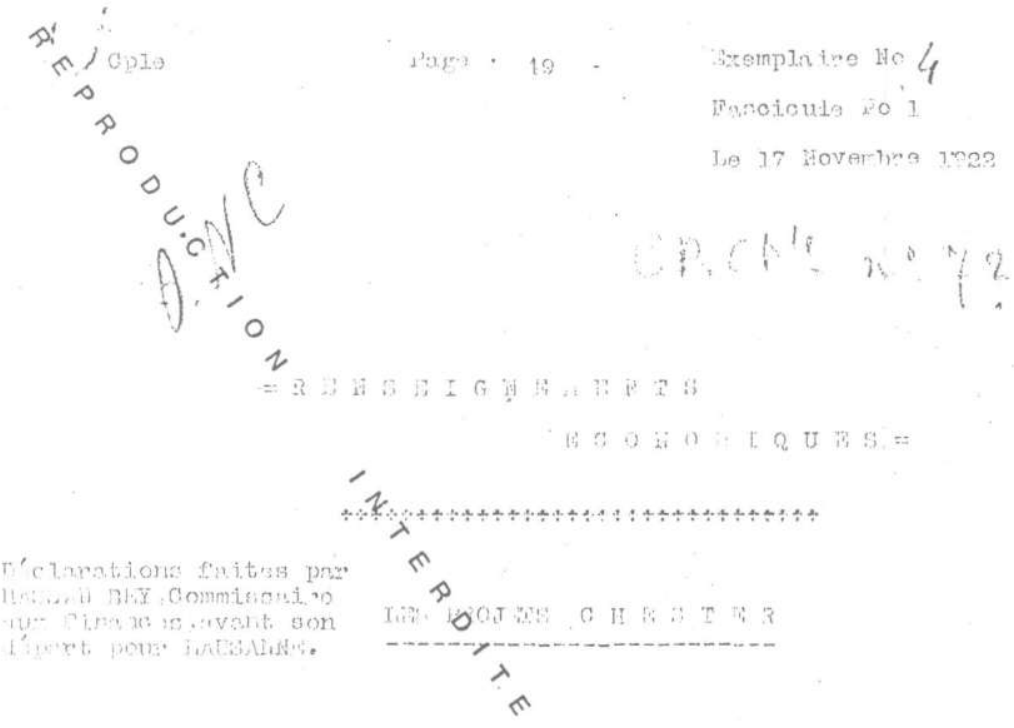

Lers projets CHEST:?

Du "BTA1:0U2" du 11.11.22.

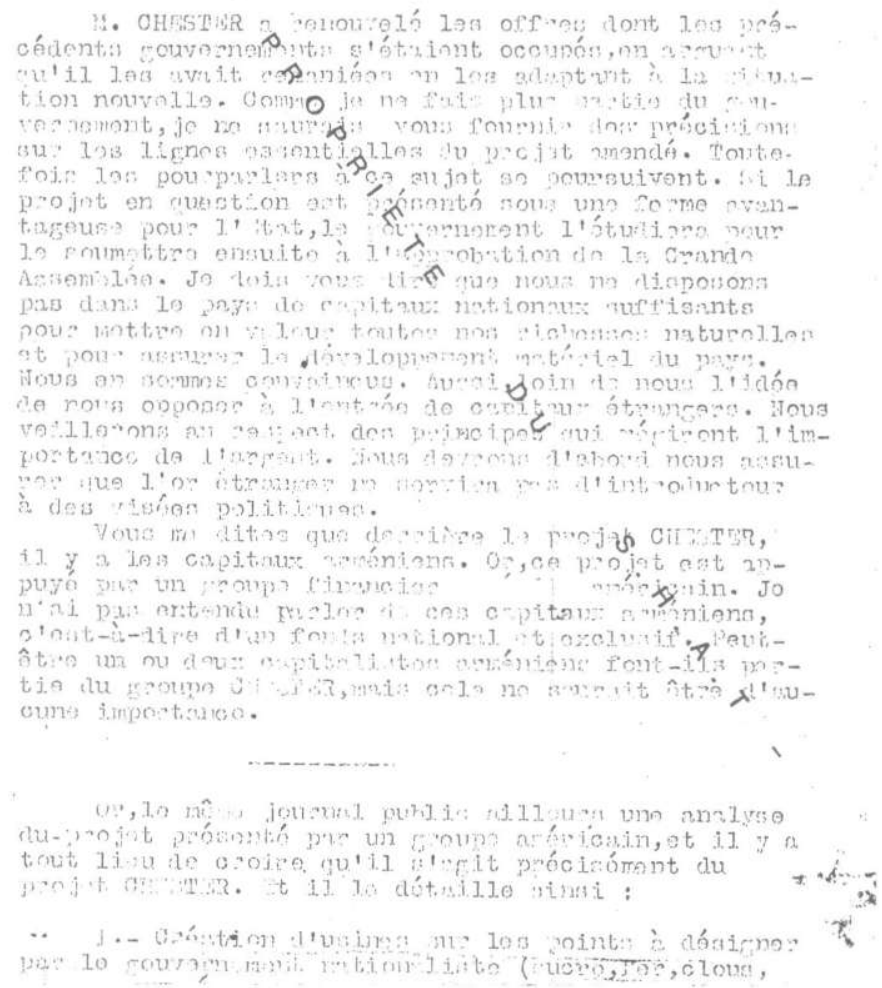

EK IV- Eski Maliye Vekili Hasan (Saka) Bey'in Lozan'a hareket etmeden önce Chester Projesi ile ilgili verdiği demeç. Château de Vincennes, 7 N 3257, D. 1, 11.11.1922 tarihli "Stamboul" Gazetesi kaynakl1, 17.11.1922 tarihli "Les projets Chester” başlıklı Fransız istihbarat raporu. 